\title{
THE ORIGIN AND NATURE OF NORMAL SYNOVIAL FLUID ${ }^{1,2}$
}

\author{
By MARIAN W. ROPES, GRANVILLE A. BENNETT, AND WALTER BAUER \\ (From the Medical Clinic of the Massachusetts General Hospital, the Departments of Medicine \\ and Pathology, Harvard Medical School, and the Massachusetts Department of \\ Public Health, Boston)
}

(Received for publication January 26, 1939)

The physical and chemical properties of normal synovial fluid have never been well established. In consequence there exists no uniformity of opinion concerning its mode of formation. If we possessed information concerning the origin and nature of normal synovial fluid, we would be in a position to interpret more correctly the abnormalities encountered in pathological joint effusions and to determine their diagnostic significance. Information of this type should also increase our knowledge of the factors involved in the production and maintenance of joint effusions.

In 1691, Havers (62), on the basis of histological examinations, concluded that synovial fluid was a secretion from synovial membrane glands. Since then various descriptions of synovial fluid and theories concerning its origin have appeared. This lack of agreement is readily explained if one examines the data upon which the various theories are based. Some of them are based solely on histological studies. Others represent conclusions drawn from chemical analyses of pathological synovial fluids. The data on pathological fluids, many of which are incomplete, vary markedly and are difficult to interpret without knowledge of the normal and a better understanding of the factors responsible for the formation of pathological fluids. The existing data pertaining to normal synovial fluid are very meagre, except for complete cytological studies $(6,73,122)$.

The various theories proposed and the data on which they are based are presented in brief.

1. That synovial fluid is the secretory product of synovial membrane cells or glands. This theory, originally proposed by Havers (62) and supported by many subsequent workers $(4,11$,

1 This is publication No. 29 of the Robert W. Lovett Memorial for the study of crippling disease, Harvard Medical School, Boston, Mass.

2 The expenses of this investigation have been defrayed by grants from the Rockefeller Foundation and the Commonwealth Fund.
$16,25,52,65,70,77,85,93,99,103,105,107$, 112 ) is based chiefly on histological examinations of synovial membrane. Drawings or photomicrographs of such glands have never been presented.

2. That synovial fluid is chiefly the product of secretion by synovial membrane cells with the addition of a transudate from the capillaries and lymphatics $(78,90)$. This theory is for the most part based on histological studies. More recently, Kling (77), on the basis of certain physical and chemical measurements of normal and pathological synovial fluids, concluded: (1) that normal synovial fluid is secreted by the synovial membrane; (2) that pathological synovial fluid contains both secretory and circulatory products.

3. That synovial fluid is a mixture of the products of disintegration of synovial membrane rubbed off during joint motion and a transudate from the capillaries and lymphatics. This theory, presented by Frerichs in 1846 (45), has been supported in a modified form by other workers (1, $21,31,35,56,57,59,100,110)$. Here again, histological studies serve as the chief basis for such conclusions.

4. That synovial fluid is formed as a result of destruction of cartilage because of constant use. Originally proposed by Ogston (97) and Banchi (5), this theory has received no support except for the statement by Fisher (35), in which he suggested that a portion of the synovial fluid mucin might be derived from articular cartilage as it becomes worn.

5. That synovial fluid is a dialysate from the blood capillaries. This theory was first suggested by Bichat (12) in 1812. He concluded that the "glands" described by Havers were fat deposits and that synovial fluid is formed directly by " exhalation" of the blood capillaries. This theory has been proposed by many workers $(2,8,13,20$, $27,46,64,69,72)$. More recent reviews (98, 102) of the existing data on synovial fluid have led to the conclusion that synovial fluid is in ready 
diffusion equilibrium with plasma and except for the presence of mucin would be considered a diffusate or a simple ultrafiltrate of serum. Such conclusions are based on histological studies or on incomplete chemical analyses of pathological synovial fluids except for those of Peters (98) which represent conclusions based on our data.

6. That synovial fluid is the specialized fluid matrix of a specialized connective tissue lining an enlarged tissue space, the joint cavity $(23,68$, $71,75)$. According to this theory, which is based on analogy with no experimental evidence except histological studies, the synovial fluid mucin corresponds to the mucoid constituent of other connective tissues. The conception of mucin as the ground substance of synovial tissue (116) is in accord with this theory.

Discussion of these theories at this time is unnecessary. It is sufficient to state that no one of them has gained general acceptance because knowledge of the physical and chemical properties of synovial fluid has been insufficient to allow one to speak with certainty concerning its origin or its nature.

In the present investigation, extensive physical and chemical analyses of simultaneously obtained arterial blood and normal synovial fluid were made. It was hoped that a complete characterization of normal synovial fluid, a comparison of the distribution ratios of electrolytes and non-electrolytes between serum and fluid with those for other body fluids and in vivo dialysates and anatomical studies would allow us to conclude which one of the previously mentioned theories is correct.

In smaller laboratory animals and in man, normal synovial fluid is present in such small amounts that aspiration is difficult. Furthermore, analyses of such small quantities of synovial fluid would necessitate the use of microchemical methods. These difficulties are readily overcome if one resorts to young western cattle because the astragalotibial joint contains a large amount of readily available normal synovial fluid. Therefore, the present studies were made on arterial blood and synovial fluid obtained from young western cattle immediately after they had been slaughtered. It was impossible to have the animals under standard conditions. During the week previous to slaughter, they had been transported in cattle cars and presumably had stood for abnormally long periods of time. At the time of slaughter, they were not fasting and had not been at rest.

The synovial fluid was aspirated from the astragalotibial joint under paraffin oil. The amount of fluid obtained from a single joint varied between 20 and $50 \mathrm{cc}$. Any obviously abnormal fluids (presumably produced by previous trauma) such as blood-tinged, deep yellow, or turbid fluids were discarded. Blood was obtained from the carotid arteries under paraffin oil. No anticoagulant was employed. The blood and the fluid were kept on ice until centrifuged, some 60 or 80 minutes later.

The total quantity of synovial fluid obtained from these animals may have been greater than normal because the animals had stood for abnormally long periods of time in transit East. In man under such conditions, transudation of an essentially protein-free fluid from the blood capillaries into the tissues of the leg takes place (80, $84,111,125)$. If similar transudation of an essentially protein-free filtrate occurred in these cattle, some dilution of the normal synovial fluid may have resulted. Membrane equilibrium, if present, should be maintained, however, despite the increased amount of fluid.

The following chemical methods were used: ${ }^{8}$ chloride, Eisenmann modification of the Van Slyke method (30) ; carbon dioxide content, Van Slyke and Neill (114); inorganic phosphate, Fiske and Subbarow (40); sodium, Rourke's modification of the Kramer-Gittleman method (101); potassium, Fiske and Litarczek (37) ; calcium, Fiske and Logan (38); magnesium, Fiske and Logan (39); nonprotein nitrogen, Folin and $\mathrm{Wu}(42)$; uric acid, Benedict and Behre (9); urea, Lieboff and Kahn (86) ; sugar, Folin (41); total base, Fiske (36); sulphate, Fiske (36); freezing point, Beckmann (34) ; fatty acids, Stoddard and Drury (108); cholesterol, Bloor (14); lactic acid, Friedemann, Cotonio, and Shaffer (47) ; osmotic pressure was determined by the Krogh method $(79,81)$, using collodion membranes which were made according to Krogh's

\footnotetext{
8 We are indebted to Dr. D. F. Loewen for the osmotic pressure readings; to Dr. C. Daley for the determination of the temperature coefficients; to Miss $D$. Sloane for the freezing point determinations, and to Mrs. D. Gilligan and Miss M. Rourke for the potassium estimations.
} 
directions and had minute numbers from 100 to 200 as described by Zsigmondy (126). The $\mathrm{pH}$ was determined by means of a McInnis glass electrode, measurements being made at $25^{\circ}$ to $28^{\circ}$ and corrected to $37^{\circ}$ by the use of a temperature coefficient. The temperature coefficient for the $\mathrm{pH}$ of synovial fluid was found to be approximately half that for serum $(\Delta \mathrm{pH} / \Delta t=0.006$ for synovial fluid, 0.012 for serum). In the first fifteen cases, the $\mathrm{pH}$ was not determined but was calculated from the Henderson-Hasselbalch equation. The carbon dioxide tension used in the equation was estimated from the carbon dioxide content and the carbon dioxide absorption curves (109). Specific gravity was determined by the use of specific gravity bottles with open capillary outlet of the type described by Moore and Van Slyke (94). Total solids were determined by drying a weighed sample of approximately 1 gram at $100^{\circ} \mathrm{C}$. for 48 hours. Viscosity was determined both by a Hess viscosimeter and by an Ostwald viscosity pipette.

The protein, other than mucin, was calculated from the total nitrogen (obtained by a modified macro-Kjeldahl method). The difference between the total nitrogen and the sum of the nonprotein and mucin nitrogen was multiplied by the factor, 6.25. Mucin was determined by precipitation with 1 per cent acetic acid and reprecipitation with acetic acid from a 0.1 per cent sodium carbonate solution. The difference in total nitrogen before and after precipitation, representing the mucin nitrogen, was converted to mucin by the factor, 8.14 (the factor of 8.14 has been obtained in this laboratory by analysis of pure mucin). In cases in which the mucin was not determined, an estimated mucin nitrogen of 0.015 grams per $100 \mathrm{cc}$. was used for calculation of the protein. Albumin and globulin contents were determined both by a modification of the Howe method (67) and by the method of Butler and Montgomery (18).

\section{RESULTS}

Fifteen joint fluids and sera were analyzed in great detail, and 45 other fluids and sera were analyzed in part. In Table I are given the values for cytology and chemical composition in the fifteen fluids analyzed in detail. The chemical constituents are expressed in concentration for each
1000 grams of water in the serum or fluid. In these fifteen cases the water content was obtained from determinations of the total solids and specific gravity. Calculated values for the water content of these same fluids were obtained for comparison by the use of the formula $W=99.6-0.85 P$, where $W$ is the water content in grams per 100 cc. and $P$ represents the grams of protein per 100 cc. The calculated values also are given in Table I and are seen to be in close agreement with the observed values. In fluids in which the water content was not determined directly, it was calculated from the above formula. In calculating the equivalent bicarbonate, $1 / 21$ of the carbon dioxide content of the fluid or serum was assumed to represent free carbonic acid. The proportions of primary acid phosphate, $\mathrm{BH}_{2} \mathrm{PO}_{4}$, and secondary phosphate $\mathrm{B}_{2} \mathrm{HPO}_{4}$, in the serum and the fluid were calculated from the Henderson formula:

$$
\begin{aligned}
& \mathrm{pH}=\mathrm{pK}^{\prime}+\log \frac{\mathrm{B}_{2} \mathrm{HPO}_{4}}{\mathrm{BH}_{2} \mathrm{PO}_{4}}, \\
& \text { using the value for } \mathrm{pK}^{\prime} \text { in blood as } 6.8 \text {. }
\end{aligned}
$$

The results will be presented under the headings of cytology, physical characteristics, protein constituents, distribution of non-electrolytes, enzymes, and distribution of electrolytes. In each case the findings will be compared with those found by other workers for synovial fluid and other body fluids. The results will be analyzed with the aim of determining whether they provide evidence that would indicate whether or not synovial fluid is a dialysate in equilibrium with blood plasma. Experiments with dialysis in vitro are, in general, not acceptable as evidence in the solution of this problem because all such experiments are open to question since absolute physiological conditions are not reproduced. Therefore, the problem can be studied best by a determination of the distribution of substances between arterial serum and synovial fluid and a comparison with the ratios expected in accord with the known physicochemical laws of equilibrium across semi-permeable membranes. Further evidence can be obtained by a comparison of the distribution ratios with those of the same substances between serum and the in vivo dialysate (55), and between serum and other body fluids which have been shown to have the composition of dialysates of blood plasma (lymph and edema fluids). Recent studies on 
the nature of lymph and edema fluids have given results in accord with those obtained by dialysis and with those expected from the laws of membrane equilibrium. Recent workers agree that the concentrations of inorganic constituents of lymph and edema fluids are such that these fluids may be regarded as ultrafiltrates or dialysates in equilibrium with plasma. (See review of subject by Landis (83).)

\section{Cytology}

Normal cattle synovial fluid is relatively acellular. The average nucleated cell count of this series is 131 cells per cu. mm., with a maximum of 250 and a minimum of 65 . The erythrocyte counts show an average of 194 , with a maximum of 1540 and a minimum of 0 . These values are in accord with those obtained in two large series of fluids from normal cattle joints $(6,122)$ -the average nucleated cell counts in these series being 112 and 182 respectively and the average red blood cell counts being 64 and 141. Differential leukocyte counts were not done in this present study as the series of Warren, Bennett, and Bauer (122) had established the average differential counts in fluid from the astragalotibial joints of normal cattle and had indicated the wide variations in phagocytic and non-phagocytic cell percentages which may occur in normal joints. They reported an average differential nucleated cell count of polymorphonuclear leukocytes, 2.2 per cent ; monocytes, 36.4 per cent ; clasmatocytes, 15 per cent ; unclassified phagocytes, 3.9 per cent ; lymphocytes, 40.1 per cent ; synovial cells, 1.2 per cent; unclassified cells, 1.2 per cent.

Few other workers have studied the cytology of normal fluid. Key (73) studied fluid from the shoulder joints of rabbits and found 175 to 225 nucleated cells per cu. mm. and approximately the same number of red blood cells (74). The differential nucleated cell count was : synovial lining cells, 3 per cent; primitive cells (resembling small lymphocytes), 1 per cent; polymorphonuclear leukocytes, 5 per cent; monocytes, 58 per cent ; clasmatocytes, 15 per cent and indeterminate phagocytes, 14 per cent. Labor and Von Balogh (82) found 10 to 20 cells per cu. mm. in fluid obtained postmortem from human joints, and McEwen (91), in two normal human fluids, found total nucleated cell counts of 125 and 200 per cu. $\mathrm{mm}$. In the fluid from knee joints of amputated legs, Kling (76) found 10 to 50 cells per cu. $\mathrm{mm}$. Forkner (43) from a review of previous studies assumed that normal synovial fluid contained \pm 50 nucleated cells per cu. mm.

The cytology of 29 fluids obtained postmortem from human joints showing no evidence of disease has been studied in this laboratory (127). The average nucleated cell count was 63 per cu. $\mathrm{mm}$. with an average differential count: polymorphonuclear leukocytes, 6.5 per cent ; monocytes, 47.6 per cent ; clasmatocytes, 10.1 per cent ; unclassified phagocytes, 4.9 per cent; lymphocytes, 24.6 per cent ; synovial cells, 4.3 per cent ; unclassified cells, 2.2 per cent.

\section{Physical characteristics}

Normal synovial fluid is a clear, straw-colored, viscous liquid, which does not clot.

The average specific gravity is 1.010 with a maximum of 1.012 and a minimum of 1.009 . These figures correspond with those found by Horiye (1.008 to 1.015 ) (66) for human fluids obtained postmortem from joints in which no histological changes were found in the membrane. They are in the same range also with the values found by Gilligan, Volk, and Blumgart (49) for chest fluid (1.010 to 1.015) and edema fluid (1.008 to 1.009 ). The total protein calculated from the average specific gravity of this series by use of the formula of Moore and Van Slyke (94) is 1.029 grams per $100 \mathrm{cc}$., which is in close agreement with the observed average protein content (including mucin) of 1.02 grams per $100 \mathrm{cc}$.

The average content of total solids is 2.084 grams per 100 grams with a maximum of 3.886 and a minimum of 1.672 , as compared with an average content of 8.727 in the serum. The fluid values correspond closely with those of Horiye (66) for human fluids obtained postmortem (1.20 to 3.93 per cent). They are slightly lower than the value given by Fisher (35) for normal human fluids obtained postmortem (4.4 per cent).

The average freezing point of the fluid is $-0.535^{\circ}$ with a maximum of $-0.556^{\circ}$ and a minimum of $-0.509^{\circ}$, as compared with an average for the serum of $-0.590^{\circ}$ (as shown below). The average difference between the freezing point depression of the fluid and that of the serum $(0.0550)$ is much greater than that found 


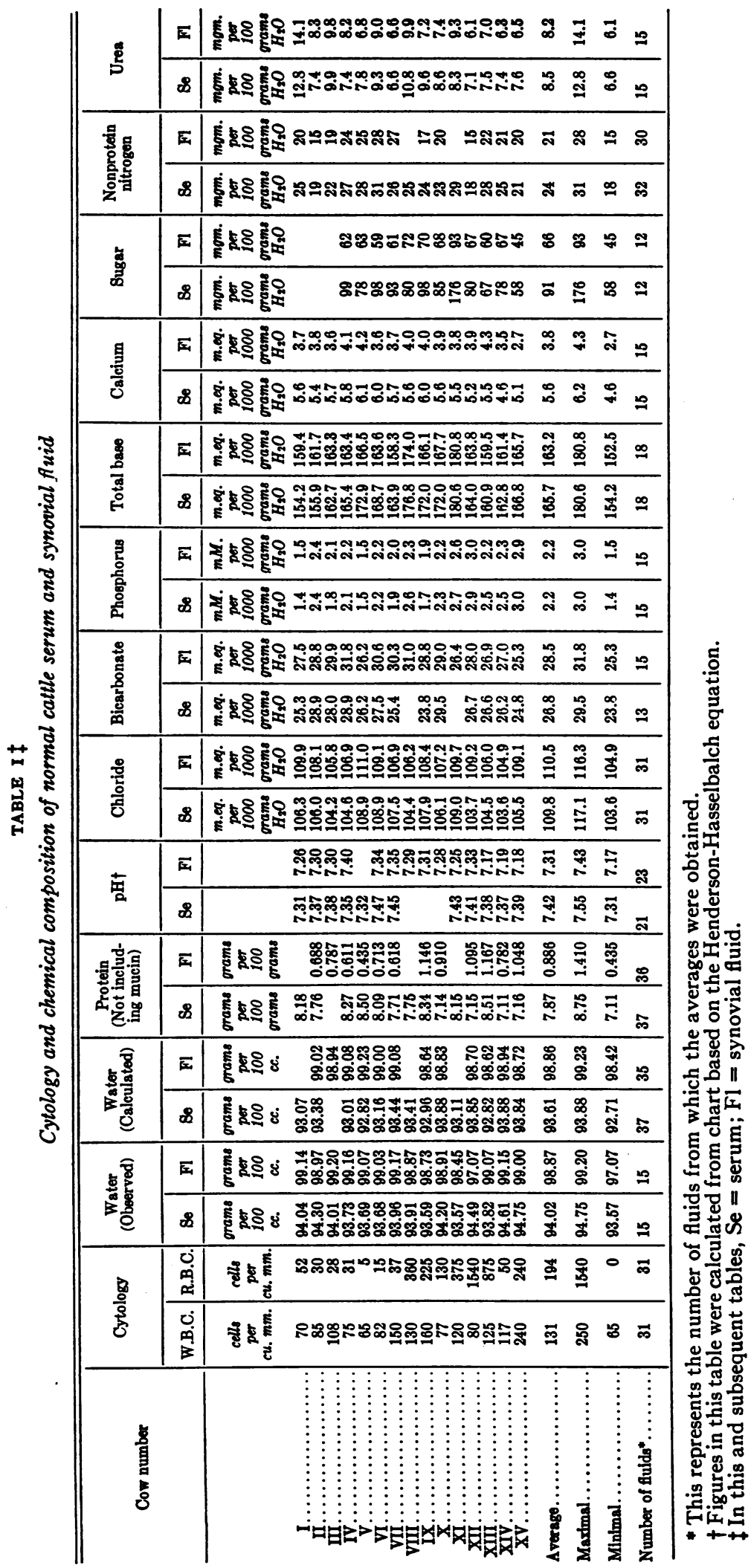


by Fremont-Smith, Thomas, Dailey, and Carroll (44) between normal spinal fluid and blood. In 62 per cent of their cases the difference was $0.005^{\circ}$ or less, and in only 21 per cent was it greater than $0.015^{\circ}$, the maximum difference being only $0.037^{\circ}$. The observed freezing points of serum and synovial fluid represent a difference in osmolar concentration of $0.030 \mathrm{M}$, and a difference in pressure of approximately 0.7 atmospheres. It is unlikely that such a difference in osmolar concentration exists. A probable explanation is that the determination of the freezing point of synovial fluid is affected in some unknown manner by the presence of the viscous mucin.

\begin{tabular}{|c|c|c|}
\hline $\begin{array}{c}\text { Cow } \\
\text { number }\end{array}$ & \multicolumn{2}{|c|}{ Se ${ }^{\text {Freezing point }} \mathrm{Fl}$} \\
\hline $\begin{array}{r}\text { XVI... } \\
\text { XVII.. } \\
\text { XVIII.. } \\
\text { XIXX.. } \\
\text { XXX.. } \\
\text { XXI.. }\end{array}$ & $\begin{aligned} & \circ C . \\
&- 0.586 \\
&= 0.587 \\
&-0.581 \\
&=0.616 \\
&=0.549 \\
&-0.622\end{aligned}$ & $\begin{array}{rl} & { }^{\circ} C . \\
- & 0.524 \\
-0.547 & 0.540 \\
-0 & 0.556 \\
-0.509 \\
-0.536\end{array}$ \\
\hline $\begin{array}{l}\text { Average } \\
\text { Maximal } \\
\text { Minimal }\end{array}$ & $\begin{array}{l}-0.590 \\
=0.616 \\
-0.549\end{array}$ & $\begin{array}{l}-0.535 \\
-0.556 \\
-0.509\end{array}$ \\
\hline
\end{tabular}

The average relative viscosity at $25^{\circ} \mathrm{C}$. is 3.72 , with variations from 2.84 to 4.15 . The viscosity is due chiefly to the presence of mucin, as shown by the fact that a value of 1.1 is obtained following precipitation of the mucin. Studies of the viscosity of normal synovial fluids have been reported only in the case of humans. Determinations made in this laboratory indicate that the viscosity is much higher in normal human fluid. Schneider (104) reported variations from 3.9 to 1490 in fluids obtained postmortem from patients who had had no joint disease.

The average osmotic pressure against RingerLocke solution is $365 \mathrm{~mm}$. of water for the serum and $150 \mathrm{~mm}$. of water for the fluid (see Table II). The average osmotic pressure difference between the fluid and the serum determined directly is $250 \mathrm{~mm}$. of water. It is of significance to compare these values with the colloidal osmotic pressure values calculated from the average albumin and globulin figures for our series, using the factors determined by Govaerts (53) for the pressure exerted per gram by serum albumin (75.4) and serum globulin (19.5). The osmotic pres- sure of the serum, calculated in this way, is $\mathbf{3 8 4}$ $\mathrm{mm}$. of water which agrees fairly well with the observed value of $365 \mathrm{~mm}$. In the case of the fluid, however, the colloidal osmotic pressure calculated from the albumin and globulin content is only $57 \mathrm{~mm}$. of water, in contrast to the observed value of $150 \mathrm{~mm}$. The other known colloidal substance in the fluid is the mucin. Little is known of the osmotic pressure exerted by mucin. If one assumes that the difference between the observed and the calculated osmotic pressures of the fluid is due to mucin, and calculates the osmotic pressure effect per gram of mucin, the value is nine times as great as that for albumin (675 as compared with 75 ).

TABLE II

Colloidal osmotic pressure of normal cattle serum and synovial fluid

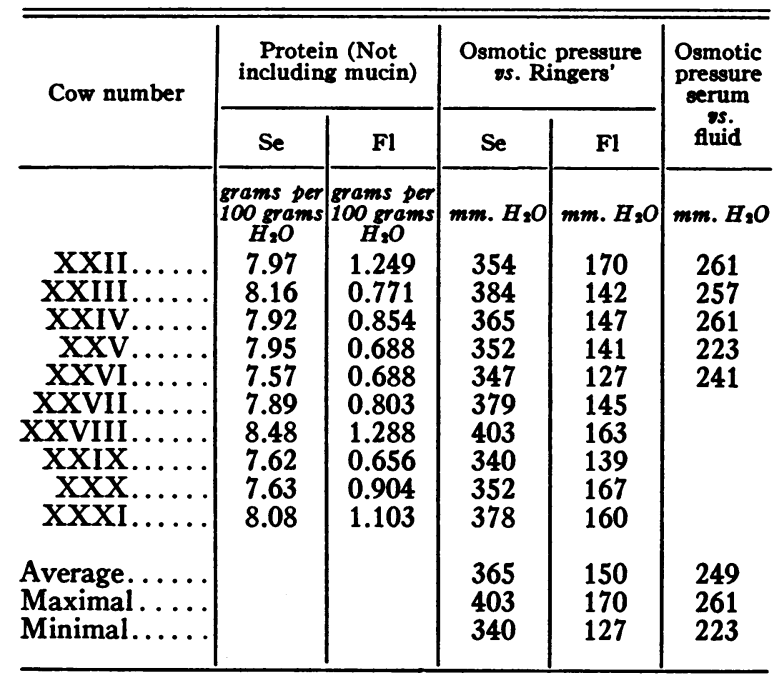

\section{Protein constituents}

The average concentration of protein in the fluid, including the mucoprotein, is 1.02 grams per 100 grams of water, in contrast to 7.87 grams per 100 grams of water in the serum. This figure is in the same range as the few values that have been reported for normal synovial fluid and somewhat lower than the values found for lymph and edema fluids. Fisher (35) found the protein of normal human fluid 1.6 per cent and of fluid from oxen 0.92 per cent. Horiye (66) found variations from 0.45 to 3.15 per cent in the protein content of fluids obtained postmortem from joints in which he found no histological changes in the membrane. From a relatively large experience 
with fluids obtained postmortem from humans without joint disease and fluids from pathological human joints, we would conclude that the value of 3.15 per cent reported by Horiye represents an abnormal fluid. Cajori and Pemberton (20), in one synovial fluid from a patient with generalized edema, found a protein of 1.39 per cent. Heim (63) reported variations from 1.38 to 4.57 per cent in the total protein of lymph, while Arnold and Mendel (3) found 3.56 per cent protein in lymph. The total protein concentrations of the fluids studied by Gilligan, Volk, and Blumgart (49) varied from 0.25 gram per 100 grams of water in one subcutaneous edema fluid to 4.36 grams in a case of ascites secondary to carcinoma. Their average value for all fluid proteins (chest, ascitic, and edema fluids) was 1.49 grams per 100 grams of water.

The content of albumin and globulin in our series is of the same general magnitude as that found by other workers for normal synovial fluid and somewhat lower than that of other fluids which have been shown to be dialysates of blood plasma. The presence of serum proteins in lymph and other body fluids has never been explained adequately. The majority of investigators (22, $24,28,32,80,121$ ) have concluded that the proteins result from a slight generalized capillary permeability to protein and subsequent concentra- tion. Other workers $(83,84,89,111)$ do not agree with these findings and have concluded that capillary permeability to proteins is negligible. The possibility of formation of the proteins in situ may be another factor but has never been investigated. The summation of evidence at present indicates that there is a slight permeability of normal capillary walls to proteins. There is no general agreement as to whether or not the permeability is sufficient to explain the concentration of protein in body fluids.

Approximately one-eighth of the fluid protein ( 0.138 gram per 100 grams of water) is mucin. It is this mucoprotein that produces most of the viscosity and the resulting lubricating value of the fluid, and, as has been discussed above, it is presumably this mucoprotein that causes part of the excessively high osmotic pressure of the fluid. By precipitation with acetic acid and reprecipitation from sodium carbonate solution, we have obtained a pure mucin, the composition and characteristics of which we shall report in a subsequent publication. The concentration of mucin found by us can be compared with the figures given by Frerichs (45) for the mucin of cattle fluid. $\mathrm{He}$ found 0.326 per cent in fluid from newborn calves, 0.24 per cent in fluid from oxen kept in stalls for long periods, and 0.56 per cent in fluid from oxen allowed free in pastures. Von Holst (117)

TABLE III

Concentrations of the protein constituents of normal cattle serum and synovial fluid

\begin{tabular}{|c|c|c|c|c|c|c|c|c|c|c|c|}
\hline \multirow{2}{*}{ Cow number } & \multicolumn{2}{|c|}{$\begin{array}{l}\text { Protein (Not } \\
\text { including mucin) }\end{array}$} & \multicolumn{2}{|c|}{$\begin{array}{l}\text { A/G ratio† } \\
\text { by NazSO، }\end{array}$} & \multicolumn{2}{|c|}{$\begin{array}{c}\text { A/G ratio } \neq \\
\text { by } \mathrm{PO}_{4}\end{array}$} & \multicolumn{2}{|c|}{$\begin{array}{c}\text { Albumint } \\
\text { by NasSO, }\end{array}$} & \multicolumn{2}{|c|}{$\underset{\text { by PO4 }}{\text { Albumint }}$} & \multirow{2}{*}{ Mucin } \\
\hline & Se & F1 & Se & Fl & $\mathrm{Se}$ & Fl & $\mathrm{Se}$ & F1 & $\mathrm{Se}$ & F1 & \\
\hline 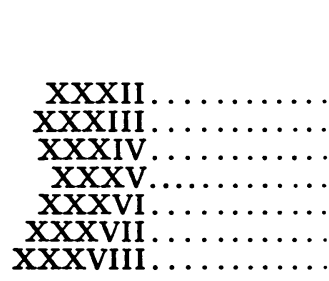 & $\mid \begin{array}{c}\text { grams per } \\
100 \text { grams } \\
H_{2} \mathrm{O} \\
7.75 \\
8.20 \\
7.33 \\
7.85 \\
7.33 \\
7.47 \\
7.38\end{array}$ & \begin{tabular}{|c|} 
grams per \\
100 grams \\
$H, 0$ \\
0.594 \\
0.743 \\
0.713 \\
1.203 \\
1.017 \\
0.911 \\
1.023
\end{tabular} & $\begin{array}{l}1.28 \\
1.25 \\
1.17 \\
1.18 \\
1.28 \\
1.38 \\
1.61\end{array}$ & $\begin{array}{l}3.81 \\
1.51 \\
1.57 \\
2.50 \\
2.51 \\
2.59 \\
2.89\end{array}$ & $\begin{array}{l}0.98 \\
1.00 \\
0.98 \\
1.02 \\
1.22 \\
1.21 \\
1.27\end{array}$ & $\begin{array}{l}4.89 \\
2.48 \\
2.82 \\
3.97 \\
5.82 \\
3.40\end{array}$ & $\mid \begin{array}{c}\text { grams per } \\
100 \text { grams } \\
H .0 \\
4.36 \\
4.55 \\
3.96 \\
4.24 \\
4.11 \\
4.32 \\
4.55\end{array}$ & $\begin{array}{c}\text { grams per } \\
100 \text { grams } \\
H 20 \\
0.470 \\
0.448 \\
0.436 \\
0.860 \\
0.727 \\
0.657 \\
0.761\end{array}$ & \begin{tabular}{|c} 
grams per \\
100 grams \\
$\mathrm{H}_{2} \mathrm{O}$ \\
3.83 \\
4.10 \\
3.64 \\
3.95 \\
4.03 \\
4.09 \\
4.14
\end{tabular} & \begin{tabular}{|c|} 
grams per \\
100 grams \\
$H_{2} \mathrm{O}$ \\
0.493 \\
\\
0.508 \\
0.889 \\
0.812 \\
0.777 \\
0.791
\end{tabular} & $\begin{array}{c}\text { grams per } \\
100 \text { grams } \\
H_{2} 0 \\
0.138 \\
\\
0.098 \\
0.212 \\
0.147 \\
0.252 \\
0.155\end{array}$ \\
\hline 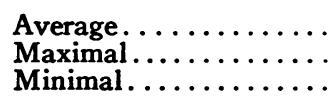 & $\begin{array}{l}7.87 \\
8.75 \\
7.11\end{array}$ & $\begin{array}{l}0.886 \\
1.410 \\
0.435\end{array}$ & $\begin{array}{l}1.31 \\
1.61 \\
1.17\end{array}$ & $\begin{array}{l}2.48 \\
3.81 \\
1.51\end{array}$ & $\begin{array}{l}1.10 \\
1.27 \\
0.98\end{array}$ & $\begin{array}{l}3.90 \\
5.82 \\
2.48\end{array}$ & $\begin{array}{l}4.30 \\
4.55 \\
3.96\end{array}$ & $\begin{array}{l}0.623 \\
0.860 \\
0.436\end{array}$ & $\begin{array}{l}3.97 \\
4.14 \\
3.64\end{array}$ & $\begin{array}{l}0.712 \\
0.889 \\
0.493\end{array}$ & $\begin{array}{l}0.138 \\
0.252 \\
0.033\end{array}$ \\
\hline Number of fluids ${ }^{*}$ & 37 & 36 & 7 & 7 & 7 & 6 & 7 & 7 & 7 & 6 & 11 \\
\hline
\end{tabular}

* This represents the number of fluids from which the averages were obtained.

+ Method of Howe (67).

$\mp$ Method of Butler and Montgomery (18). 
found 0.5 per cent mucin in normal cattle fluid. Fisher (35) found 1.95 per cent mucin in normal human fluid and only 0.13 per cent in fluid from oxen. Cajori and Pemberton (20) report a mucin content of 0.42 per cent in fluid from a patient with generalized edema.

The globulin fraction of the fluid protein, as determined by precipitation with 22.5 per cent sodium sulphate, averages 0.26 gram per 100 grams of water, with an average albumin content of 0.62 gram per 100 grams of water. (See Table III.) The average albumin-globulin ratio of the fluid is 2.5 , in contrast to an average ratio of 1.3 in the serum. When the protein fractions are determined by the method of Butler and Montgomery (18), using a $2.3 \mathrm{~m}$ solution of phosphate, the value obtained for the albumin fraction of serum is lower than that obtained by sodium sulphate precipitation. The resulting albumin-globulin ratio is somewhat lower (1.1). This is in accord with the results of the two methods as reported by Butler and Montgomery. In the case of the fluid, however, the albumin concentration determined by precipitation with phosphate is consistently higher than that obtained by precipitation with sodium sulphate. This finding is presumably due to the loss of albumin during the precipitation of globulin by sulphate, which has been shown to occur when the total protein content is low $(50,67)$. Experiments performed in this laboratory with dilutions of serum have shown that no such loss of albumin occurs with phosphate precipitation. The albumin-globulin ratio of the fluid as determined by precipitation with phosphate is, therefore, higher (3.9) than that obtained by precipitation with sulphate (2.5), and gives a more accurate representation of the protein fractions as accepted at present.

In all of the determinations of the protein fractions, the mucin nitrogen was subtracted from the difference between the total protein nitrogen and albumin nitrogen in order to obtain the globulin nitrogen. The accuracy of the albumin concentration obtained by precipitation with either sulphate or phosphate solutions even in a mucincontaining solution has been proved in this laboratory by precipitation experiments on solutions of pure mucin in serum. These experiments have shown that mucin is precipitated with the globulin fraction of the fluid when either sulphate or phosphate solutions are used.

The globulin concentration and the albuminglobulin ratio varied more in the fluid than in the serum, as was found in the case of pathological fluids by Cajori and Pemberton (20). Similarly, marked variations in the albumin-globulin ratio in other body fluids were found by Gilligan, Volk, and Blumgart (49). This may be due in part to less accuracy in separation of the protein fractions when the total protein content is low, and in part to slight variations in capillary permeability.

The comparatively low globulin concentration and high albumin-globulin ratio of the fluid in contrast to those of the serum is in accord with the results found by Field, Leigh, Heim, and Drinker $(29,33)$ for lymph and edema fluid, and with the findings of Wells (124), and Weech, Goettsch, and Reeves (123) and of Goettsch and Kendall (50) in lymph, edema fluid, and ascitic fluid. Assuming that the serum proteins of the fluids result from slight capillary permeability, the high albumin-globulin ratio in the fluids indicates greater capillary permeability to albumin than to globulin. The difference is in accord with the difference in molecular weights of albumin and globulin, and with the variation in their rates of removal from joints (7).

Normal fluid contains no fibrinogen as suggested by the failure to clot after standing twentyfour hours. The absence of fibrinogen has been corroborated in this laboratory by precipitation experiments with $1.1 \mathrm{M}$ phosphate solutions at $\mathrm{pH} 6.5$.

\section{Distribution of non-electrolytes}

The average concentration of urea in the fluid (expressed in milligrams per 100 grams of water) is slightly lower than that in the serum but is essentially of the magnitude that would be expected if serum and fluid were separated by a membrane permeable to this substance. The distribution ratios of total nonprotein nitrogen $(0.87)$ and uric acid (0.84) between fluid and serum are somewhat lower than that of urea, but they are of the same general magnitude. These findings are in accord with those reported by Hare and Cohen (58) for normal horse syno- 
vial fluid, and by other workers for pathological fluids $(2,19,20,23,96)$.

Although the average distribution ratios for urea, uric acid, and nonprotein nitrogen between fluid and serum are slightly below 1.00 , analysis of the results of determinations in individual sera and fluids shows many cases in which the concentrations of these non-electrolytes are as high in the fluid as in the serum (see Table I and figures given below). These individual cases, in themselves, give proof that the non-electrolytes (urea, uric acid, and nonprotein nitrogen) are completely diffusible through the membrane separating serum and fluid. We have found further evidence of the complete diffusibility of these nonelectrolytes in our results on normal and pathological human fluids which will be reported in a later publication. In the majority of those cases, the distribution ratio of nonprotein nitrogen and uric acid between fluid and serum closely approaches 1.00 .

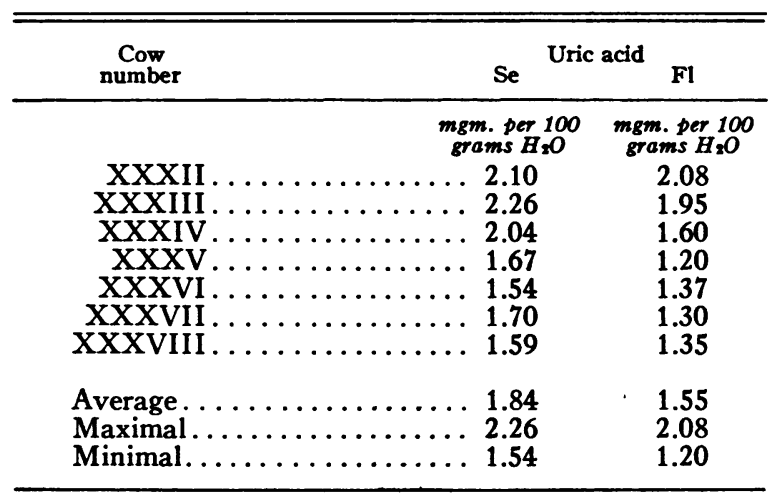

The average concentration of sugar in the present series is, on the other hand, much lower in the fluid than in the serum. The values in individual cases vary much more than those for any other substance. The marked variations in values and the lower concentration in the fluid may be due in part to the fact that the animals were not fasting, and in part to the fact that they struggled considerably when sacrificed, thereby raising the concentration of sugar in the serum just before the samples were collected and not allowing time for the fluid to come to equilibrium with the serum. That this is the explanation, rather than the presence of a non-diffusible portion of glucose in the serum as suggested by Brull (17), is apparent from our findings in human fluids, which will be reported in detail in a later publication. In many of these cases, the distribution ratios of sugar between fluid and serum closely approach 1.00. This is in accord with the results of Walker and Reisinger (120) who found complete diffusion of reducing substances between plasma and glomerular urine.

Cholesterol and fatty acids are absent in the fluid. This is in accord with the generally accepted theory that the capillary membrane under normal conditions is not permeable to these substances.

Thus, the distribution of non-electrolytes is consistent with the theory that synovial fluid is a dialysate of blood plasma.

\section{Enzymes}

Except for the determination of the phosphatase activity of fluid and serum, no enzyme studies were undertaken. The fluids were found to have a higher average phosphatase activity than the serum. Greater variations were encountered in the fluids. Further studies are needed in order to explain such variations.

\section{Distribution of electrolytes}

The concentrations of chloride and bicarbonate are higher in the fluid than in the serum while the concentrations of sodium, potassium, calcium, and magnesium are lower in the fluid than in the serum. The concentration of total inorganic phosphate is practically the same in fluid and serum. These distributions, are, in general, such as would be expected from consideration of the laws regulating membrane equilibrium. They will be analyzed in detail below.

The excess of chloride in the fluid bears about the same relation to the excess of protein in the serum as has been found by other workers for lymph, edema fluids, and the in vivo dialysate. The relationship may be graphically presented as was done by Gilligan, Volk, and Blumgart (48). The excess of chloride in the fluid in proportion to the excess of protein in the serum, however, is slightly lower than that found for the other fluids (Chart I). This may be related to the nature and relative concentration of the proteins in synovial fluid. The high albumin-globulin ratio in the fluid would tend to increase the basebinding power per gram of total protein. The 


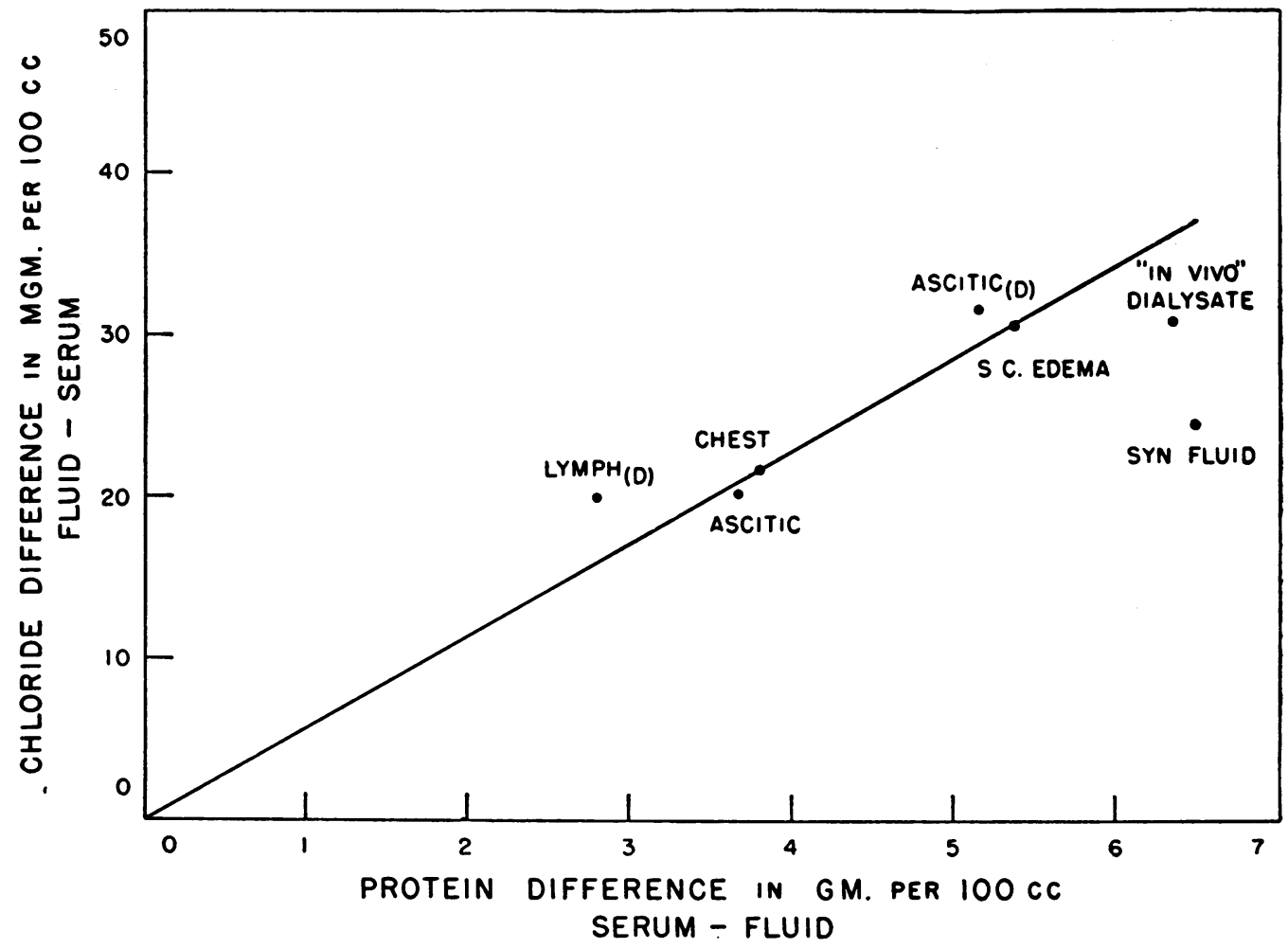

Chart I. The Relationship between the Difference in Chloride Concentration of Various Body Fluids and Serum and the Difference in their Protein Concentrations

The values charted represent average values from the following studies: chest fluid, total of 14 observations $(49,54,87)$; lymph, dogs, total of 7 observations $(3,63)$; ascitic fluid, total of 18 observations $(49,54,61,87)$; ascitic fluid, dogs, total of 10 observations (54); subcutaneous edema fluids, total of 16 observations $(49,51,61)$; in vivo dialysates, dogs, total of 15 observations (55); synovial fluid, total of 15 observations from our studies.

presence of mucin may further increase the basebinding power, as indicated by the results of solubility experiments on pure mucin now in progress. In addition, the isoelectric point of mucin (approximately $\mathrm{pH} 4.0$ ) is farther from the $\mathrm{pH}$ of fluid than are the isoelectric points of albumin or globulin with the result that at $\mathrm{pH} 7.4$ it has a considerable degree of combination with base.

\section{Hydrogen-ion concentration}

The average $\mathrm{pH}$ of the fluid is 7.31 as compared with an average $\mathrm{pH}$ of 7.42 for the serum. The averages include the values calculated from the Henderson-Hasselbalch equation (Table I) and the values determined by means of the glass electrode (listed below). Few reports of the $\mathrm{pH}$ of normal synovial fluid have been made. Horiye (66) found fluid obtained postmortem from human joints to be weakly alkaline to litmus.
Seeliger (106) reported the $\mathrm{pH}$ of postmortem fluid as 8.2 to 8.4. Boots and Cullen (15) found a $\mathrm{pH}$ of 7.34 in fluid from a patient with generalized edema.

\begin{tabular}{|c|c|c|}
\hline $\begin{array}{c}\text { Cow } \\
\text { number }\end{array}$ & $\mathrm{Se}$ & $\mathrm{pH}$ \\
\hline $\begin{array}{r}\text { XXXII } \\
\text { XXXIII } \\
\text { XXXIV } \\
\text { XXXV } \\
\text { XXXVI } \\
\text { XXXVII } \\
\text { XXXVIII }\end{array}$ & $\begin{array}{l}7.55 \\
7.49 \\
7.47 \\
7.52 \\
7.45 \\
7.42 \\
7.40\end{array}$ & $\begin{array}{l}7.43 \\
7.39 \\
7.39 \\
7.31 \\
7.27 \\
7.27 \\
7.35\end{array}$ \\
\hline
\end{tabular}

The $\mathrm{pH}$ of 7.31 found in the synovial fluid is of interest. In other body fluids which have the composition of dialysates the fluid $\mathrm{pH}$ has been found to be slightly higher ( 0.02 to 0.05 unit) than that of the serum $(61,87)$. In the case of synovial fluid the $\mathrm{pH}$ is 0.11 unit lower than the 
serum $\mathrm{pH}$. The low $\mathrm{pH}$ of the fluid is associated with an exceptionally high carbon dioxide tension (an average of $58.8 \mathrm{~mm}$., as shown in the tabulation below). The corresponding $\mathrm{pH}$ and carbon dioxide tension values of the serum were in the normal range. The explanation of the values found in the fluid is not apparent.

\begin{tabular}{|c|c|c|}
\hline \multirow[t]{2}{*}{$\begin{array}{c}\text { Cow } \\
\text { number }\end{array}$} & \multicolumn{2}{|c|}{$\underset{\mathrm{Se}}{\text { Carbon dioxide tension }} \mathrm{Fl}$} \\
\hline & $m m$. & $m m$ \\
\hline I. & 48.8 & 59.1 \\
\hline II. & 48.9 & 56.8 \\
\hline III. & 46.4 & 58.9 \\
\hline IV. & 51.1 & 50.4 \\
\hline $\mathrm{V}$ & 49.5 & \\
\hline VI. & 37.4 & 55.3 \\
\hline VII & 36.1 & 53.6 \\
\hline VIII. & & 62.5 \\
\hline IX & & 55.6 \\
\hline $\mathrm{X}$ & & 59.7 \\
\hline XI. & & 58.0 \\
\hline XII. & 41.4 & 51.7 \\
\hline XIII. & 44.1 & 70.1 \\
\hline & 44.3 & 67.4 \\
\hline $\mathrm{XV}$ & 40.2 & 64.6 \\
\hline & 44.4 & 58.8 \\
\hline Maximal & 51.1 & 70.1 \\
\hline Minimal & 36.1 & 50.4 \\
\hline
\end{tabular}

Application of the Gibbs-Donnan theory of membrane equilibrium

The significance of this theory as applied to the equilibrium between plasma and body fluids is recognized, even though the inability to determine with any degree of accuracy either the activities of ions in so complex a system, or the presence of other modifying factors, makes it impossible to obtain exact mathematical agreement between calculated and observed values. By this theory the distribution of ions is expressed mathematically by the equation:

$r=\frac{(\mathrm{Cl}) s}{(\mathrm{Cl}) f}=\frac{\left(\mathrm{HCO}_{3}\right) s}{\left(\mathrm{HCO}_{3}\right) f}=\frac{(\mathrm{Na}) f}{(\mathrm{Na}) s}=\frac{(\mathrm{K}) f}{(\mathrm{~K}) s}, \quad$ etc.

These equations hold strictly only when expressed in terms of activities of the various ions. However, they can be assumed to be valid when expressed in terms of concentrations if we assume that the diffusible salts are ionized to an equal extent in serum and fluid and that the activity coefficients of the ions in the two fluids are not significantly different.

In order to determine whether our results are in accord with the Donnan theory, the approxi- mate Donnan distribution ratio has been calculated, using the formula derived by Van Slyke, $\mathrm{Wu}$, and McLean (115), and estimating the base bound by protein by means of the formula of Van Slyke, Hastings, Hiller, and Sendroy (113). The theoretical average Donnan ratio for our studies is 0.933 . The distribution ratios determined by us are compared in Table IV with this theoretical Donnan ratio and with the ratios found by Greene and Power (55) for in vivo dialysates and those found by the following workers for various body fluids : Gilligan, Volk, and Blumgart (49), Gollwitzer-Meier (51), and Loeb, Atchley, and Palmer (87), edema fluid; Arnold and Mendel (3) and Heim (63), lymph; Darrow, Hopper, and Carey (26), Greene, Bollman, Keith, and Wakefield (54), Muntwyler, Way, and Pomerene (95), ascitic fluid; Hastings, Salvesen, Sendroy, and Van Slyke (61), ascitic and edema fluids.

The average distribution ratios between serum and synovial fluid of chloride, bicarbonate, inorganic phosphate, sulphate and total anions, as found in our studies, are all of the same order of magnitude.

The average ratio $\frac{(\mathrm{Cl}) s}{(\mathrm{Cl}) f}$ is 0.99 which conforms fairly well with those found for other fluids. It is 6 per cent higher than the average Donnan ratio, a deviation from the theoretical approximately the same as that found by Greene and Power (55) in the case of the in vivo dialysate. The discrepancy may be, as they suggest, due in part to the fact that the base proteinate is not completely ionized as is assumed in calculating the theoretical Donnan ratio. It may, however, be due in part also to the high albuminglobulin ratio and the mucin content of the fluid, both of which tend to increase the base-binding power per gram of total protein.

The average ratio $\frac{\left(\mathrm{HCO}_{3}\right) s}{\left(\mathrm{HCO}_{3}\right) f}$ is 0.94 , which is in close agreement with the theoretical Donnan ratio, and conforms fairly well with the bicarbonate ratio found for other fluids. Deviation from the chloride ratio may depend on several factors. The bicarbonate ratio represents that between arterial blood and fluid, and, as would be expected, this ratio has been found by various workers to be lower than that between venous 
TABLE IV

Comparison of distribution ratios between serum and various body fluids

\begin{tabular}{|c|c|c|c|c|c|c|c|c|c|c|c|c|c|}
\hline \multirow{3}{*}{ Ratio } & \multirow{2}{*}{$\begin{array}{c}\text { Present } \\
\text { series }\end{array}$} & \multirow{2}{*}{$\begin{array}{l}\text { Gilligan } \\
\text { et al. } \\
(49) \\
\text { Edema } \\
\text { fluids }\end{array}$} & \multirow{2}{*}{$\begin{array}{c}\text { Greene and } \\
\text { Power } \\
\text { (55) } \\
\text { in vivo } \\
\text { dialysate }\end{array}$} & \multirow{2}{*}{$\begin{array}{l}\text { Greene } \\
\text { et al. } \\
\text { (54) } \\
\text { Ascitic } \\
\text { fluid }\end{array}$} & \multirow{2}{*}{$\begin{array}{l}\text { Greene } \\
\text { et al. } \\
(54) \\
\text { Transu- } \\
\text { dates }\end{array}$} & \multirow{2}{*}{$\begin{array}{c}\text { Gollwitzer- } \\
\text { Meier } \\
\text { (51) } \\
\text { Edema } \\
\text { fluids }\end{array}$} & \multirow{2}{*}{$\begin{array}{c}\text { Van Slyke } \\
\text { from Loeb } \\
\text { et al. (87) } \\
\text { Edema } \\
\text { fluids }\end{array}$} & \multirow{2}{*}{$\begin{array}{c}\text { Heim } \\
(63) \\
\text { Lymph }\end{array}$} & \multirow{2}{*}{$\begin{array}{c}\text { Arnold } \\
\text { and } \\
\text { Mendel } \\
(3) \\
\text { Lymph }\end{array}$} & \multicolumn{2}{|c|}{ Hastings et al. (61) } & \multirow{2}{*}{$\begin{array}{l}\text { Muntwyler } \\
\text { et al. (95) } \\
\text { Pleural } \\
\text { and ascitic } \\
\text { fluids }\end{array}$} & \multirow{2}{*}{$\begin{array}{l}\text { Darrow } \\
\text { et al. } \\
(26) \\
\text { Ascitic } \\
\text { fluids }\end{array}$} \\
\hline & & & & & & & & & & $\begin{array}{l}\text { Edema } \\
\text { fluids }\end{array}$ & $\begin{array}{l}\text { Ascitic } \\
\text { fluids }\end{array}$ & & \\
\hline & Cattle & Human & Dog & Dog & Human & Human & Human & Dog & Dog & Human & Human & Human & Human \\
\hline$\frac{\mathrm{Cl}_{s}}{\mathrm{Cl}_{f}}$ & 0.99 & 0.98 & 0.98 & 0.97 & 0.97 & 0.94 & 0.97 & 0.95 & 0.95 & 0.98 & 1.01 & 0.96 & $\mid \begin{array}{l}0.96 \text { (ven) } \\
0.98 \text { (art) }\end{array}$ \\
\hline$\frac{\mathrm{HCO}_{3 s}}{\overline{\mathrm{HCO}_{3 j}}}$ & 0.94 & $\begin{array}{l}1.01 \text { (ven) } \\
0.91 \text { (art) }\end{array}$ & 0.97 & 0.92 & 1.03 & 0.96 & $\begin{array}{l}1.06 \text { (ven) } \\
0.98 \text { (art) }\end{array}$ & & & 0.97 & 0.97 & 1.08 & $\begin{array}{l}0.99 \text { (ven) } \\
0.92 \text { (art) }\end{array}$ \\
\hline$\frac{\mathrm{PO}_{48}}{\mathrm{PO}_{4 f}} \ldots$ & 1.00 & 1.03 & 1.17 & 1.12 & 1.05 & & & 0.95 & 1.19 & & & & \\
\hline$\frac{\mathrm{Naf}}{\mathrm{Na}_{s}} \ldots$ & 0.93 & 0.96 & 0.91 & 0.94 & 0.96 & & $\mid 1.01$ & & & 0.94 & 0.93 & & \\
\hline$\frac{\mathrm{K}_{f}}{\overline{\mathrm{K}}_{\mathrm{s}}} \cdots$ & 0.75 & 0.84 & 0.78 & 0.94 & 0.75 & 0.75 & 0.60 & & & 0.71 & & & \\
\hline$\frac{\mathrm{Ca}}{\mathrm{Ca}_{8}} \ldots \ldots$ & 0.68 & 0.70 & 0.58 & 0.71 & 0.79 & & & 0.84 & & & & & \\
\hline$\sqrt{\frac{\mathrm{Ca}_{s}}{\mathrm{Ca}_{s}}}$. & 0.83 & & 0.76 & 0.83 & 0.87 & & & & & 0.80 & 0.85 & & \\
\hline$\frac{\mathrm{Mg}_{f}}{\mathrm{Mg}_{8}}$ & 0.72 & & 0.64 & 0.77 & 0.99 & & & & & & & & \\
\hline$\sqrt{\sqrt{\mathrm{Mg}_{\mathrm{Mg}}}}$. & 0.88 & & 0.66 & 0.86 & 0.99 & & & & & & & & \\
\hline $\begin{array}{c}\text { Theoretical } \\
\text { Donnan.. }\end{array}$ & 0.933 & 0.955 & 0.933 & & & & 0.97 & & & 0.962 & 0.975 & 0.957 & $\begin{array}{l}0.979 \text { (ven) } \\
0.981 \text { (art) }\end{array}$ \\
\hline
\end{tabular}

blood and fluid (see Table IV). Furthermore, the discrepancy may be due in part to variation in the carbon dioxide content of blood from the carotid artery and blood from capillaries around the knee. In addition, true equilibrium probably never exists because carbon dioxide is constantly being poured into the fluids from the tissues to be removed by the blood (98).

The average ratio $\frac{\text { (lactic acid) } s}{\text { (lactic acid) } f}$ is 2.11. The concentrations in individual cases show marked variations (as shown below). The extremely high distribution ratio and the variations in con-

\begin{tabular}{|c|c|c|}
\hline \multirow[t]{2}{*}{$\begin{array}{c}\text { Cow } \\
\text { number }\end{array}$} & \multicolumn{2}{|c|}{ Lactic acid } \\
\hline & $\begin{array}{l}\text { m.eq. per } 1000 \\
\text { grams } \mathrm{H}_{2} \mathrm{O}\end{array}$ & $\begin{array}{l}\text { m.eq. per } 1000 \\
\text { grams } \mathrm{H}_{2} \mathrm{O}\end{array}$ \\
\hline XVI. & $\cdots$ & 3.80 \\
\hline XVII. & $\ldots 8.18$ & 3.45 \\
\hline XVIII. & $\ldots 4.87$ & 3.56 \\
\hline XIX. & 9.71 & 3.57 \\
\hline $\mathrm{XX}$. & 4.14 & 2.06 \\
\hline XXI. & . 5.93 & 2.84 \\
\hline Average. & $\ldots 5.47$ & 3.21 \\
\hline Maximal & $\ldots 9.71$ & 3.80 \\
\hline Minimal & .. 4.14 & 2.06 \\
\hline
\end{tabular}

centrations in individual sera and fluids are presumably explicable as in the case of the sugar by the fact that the animals struggled considerably when sacrificed, thereby raising the lactic acid concentration in the blood and not allowing time for the fluid to come to equilibrium with the blood.

The average ratio $\sqrt{\frac{\left(\mathrm{SO}_{4}\right) s}{\left(\mathrm{SO}_{4}\right) f}}$ is $1.06,7$ per cent higher than the chloride ratio. Since the determination of sulphate in blood and fluid is not exact, the 7 per cent deviation is not of great significance, and the sulphate ratio may be con-

\begin{tabular}{|c|c|c|}
\hline \multirow[t]{2}{*}{$\begin{array}{l}\text { Cow } \\
\text { number }\end{array}$} & \multicolumn{2}{|c|}{$\mathrm{Se}$ Sulphate $\mathrm{Fl}$} \\
\hline & $\begin{array}{l}\text { m.eq. per } 1000 \\
\text { grams } \mathrm{H}_{2} \mathrm{O}\end{array}$ & $\begin{array}{l}\text { m.eq. per } 1000 \\
\text { grams } \mathrm{H}_{2} \mathrm{O}\end{array}$ \\
\hline $\begin{array}{r}\text { XVI. } \\
\text { XVII. } \\
\text { XVIII. } \\
\text { XIX. } \\
\text { XX. } \\
\text { XXI. }\end{array}$ & $\begin{array}{ll}\ldots & 6.01 \\
\ldots & 5.33 \\
\ldots & 5.31 \\
\ldots & 5.40 \\
\ldots & 5.28 \\
\ldots & 6.03\end{array}$ & $\begin{array}{l}4.75 \\
5.01 \\
4.94 \\
4.53 \\
5.11 \\
5.42\end{array}$ \\
\hline $\begin{array}{l}\text { Average } \\
\text { Maxima } \\
\text { Minima }\end{array}$ & $\begin{array}{ll}\ldots & 5.56 \\
\ldots & 6.03 \\
\ldots & 5.28\end{array}$ & $\begin{array}{l}4.96 \\
5.42 \\
4.53\end{array}$ \\
\hline
\end{tabular}


sidered in general agreement with the chloride ratio.

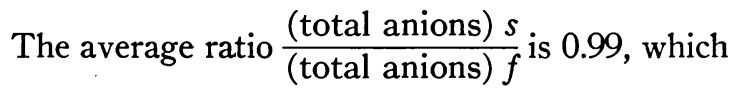
agrees well with the ratio found for the in vivo dialysate (55), and with the chloride ratio in our findings.

The average ratio $\frac{\text { (total inorganic phosphate) } s}{\text { (total inorganic phosphate) } f}$ is 1.00 . The average ratios of the primary and secondary phosphates are:

$$
\frac{\left(\mathrm{H}_{2} \mathrm{PO}_{4}\right) s}{\left(\mathrm{H}_{2} \mathrm{PO}_{4}\right) f}=0.787 \text { and } \sqrt{\frac{\left(\mathrm{HPO}_{4}\right) s}{\left(\mathrm{HPO}_{4}\right) f}}=1.03 \text {. }
$$

This is in accord with the results of Maly (88) who showed that the acid phosphates are more diffusible. However, the most important ratio in a consideration of the diffusibility of phosphate is that of the total inorganic phosphate. There has been considerable variation in the phosphate ratios between serum and dialysates, and between serum and body fluids as found by various workers. As a result, there is disagreement as to the proportion of the phosphate of the blood that is diffusible. Greene and Power (55), and Gilligan, Volk, and Blumgart (49) have concluded that part of the inorganic phosphate is held in the serum, presumably bound by protein. Brull (17), in a review of the results obtained by dialysis and vividiffusion experiments, points out that the results in general indicate that the phosphate of blood is entirely diffusible. In his own experiments, Brull found that the inorganic phosphate of serum is practically entirely diffusible, but that the majority of the inorganic phosphate of heparinized plasma is not ionized and not diffusible. Heim (63), working on lymph, and Walker $(118,119)$, working on lymph and glomerular urine, have concluded that all of the inorganic phosphate of the blood is diffusible. Our results indicate a slightly greater ratio of total inorganic phosphate than the theoretical Donnan ratio, but the phosphate ratio is within one per cent of the chloride ratio determined by us, and would indicate that the inorganic phosphate is entirely diffusible, and that its distribution is determined by the same laws of membrane equilibrium as regulate the distribution of chloride between serum and synovial fluid.

The average distribution ratios between fluid and serum of sodium, potassium, calcium, and magnesium, in contrast to those for anions, vary markedly among themselves, but they agree, in general, with the distribution ratios for the same sub-

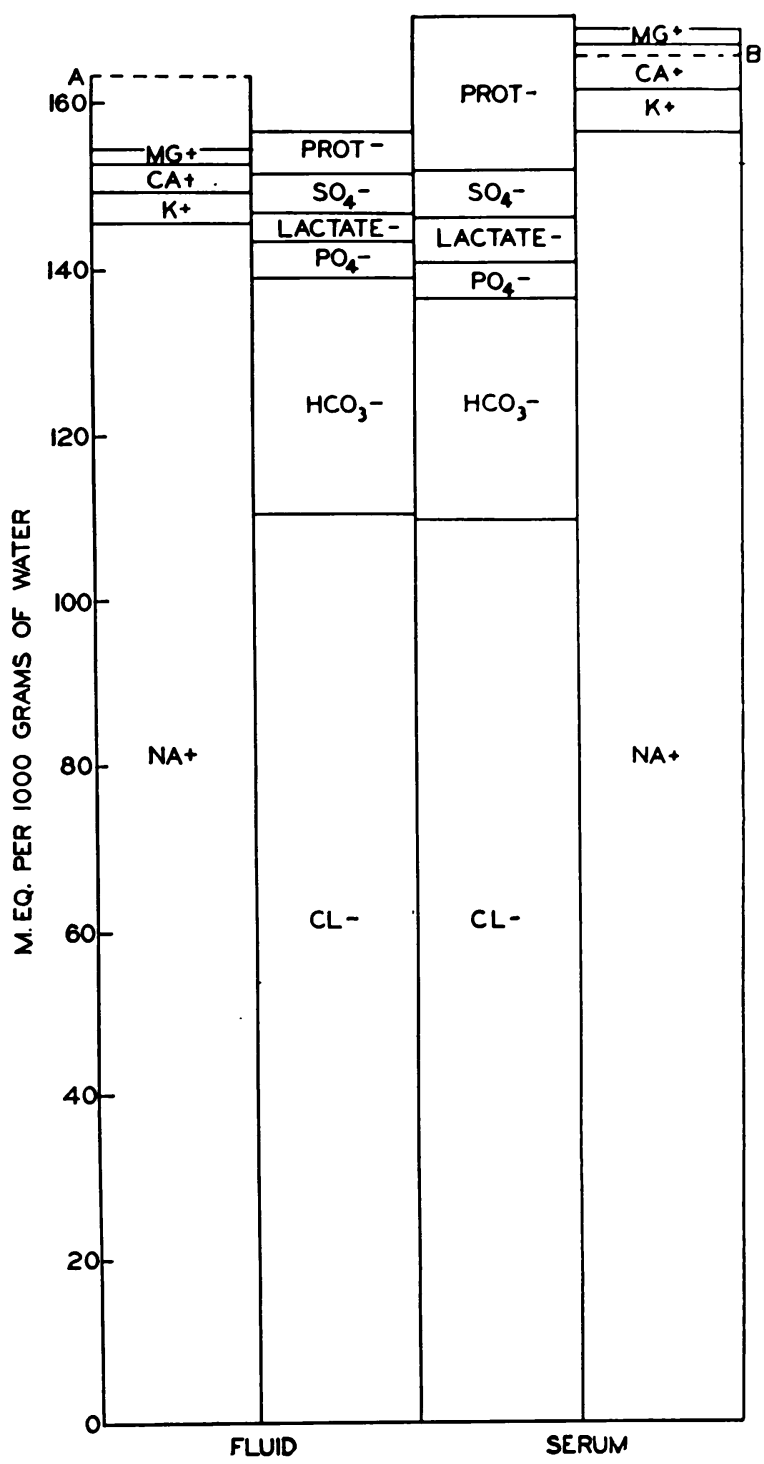

Chart II. The Distribution of Anions and Cations Between Serum and Normal Cattle Synovial FLUID

It will be noted that the summations of individual bases in the fluid and serum do not correspond exactly with the average determined total base values for fluid $(A)$ and serum $(B)$.

The formulae of Van Slyke, Hastings, Hiller, and Sendroy (113) were used in estimating the proteinate. In the case of mucin, the base-binding power was assumed to be ten times the average base-binding power of albumin and globulin. 
stances between the in vivo dialysate and serum, and between lymph and edema fluids and serum.

The average ratio $\frac{(\mathrm{Na}) f}{(\mathrm{Na}) s}$ is 0.93 , which is identical with the theoretical Donnan ratio, but slightly lower than the chloride ratio as found in our experiments. It is in fairly good agreement with the ratios found by other workers. The slight deviation from the chloride ratio may indicate that a small percentage ( 6 per cent) of the sodium is held in the serum in a non-diffusible form, presumably bound to protein. The deviation, however, may not be sufficiently great to be of significance.

The average ratio $\frac{\sqrt{(\mathrm{Ca}) f}}{\sqrt{(\mathrm{Ca}) s}}$ is 0.83 , and indicates, as do the similar calcium ratios obtained for the in vivo dialysate and other fluids, that part of the calcium is held in the serum, presumably bound to protein. This concept of nondiffusible calcium bound to protein is now generally accepted (see review by McLean and Hastings (92)). The percentage of the blood calcium thus bound has been found to be from 30 to 40 per cent. The results of our experiments give an average of 32 per cent bound. Of more significance than the distribution ratio of total calcium is that of ionized calcium. Calculation of the calcium ion in serum and fluid from the protein and total calcium concentrations (McLean and Hastings) gives a ratio $\frac{\left(\mathrm{Ca}^{++}\right) f}{\left(\mathrm{Ca}^{++}\right) s}$ of 1.18. This ratio is much higher than would be expected from the laws of membrane equilibrium. The difference may be explicable in part by the fact that, in calculating the calcium ion concentrations of the serum and fluid, no consideration was given to the difference in $\mathrm{pH}$ and albumin-globulin ratios, but in larger part by the fact that the mucoprotein was included as part of the total protein and considered to have the same effect as the serum proteins. That the last assumption is incorrect is evident from a comparison of the calcium concentration of synovial fluid with that of other body fluids known to be dialysates of blood plasma. A review of the results on all such fluids gives an average empirical ratio $\frac{(\mathrm{Ca}) \text { dialysate }}{(\mathrm{Ca}++) \text { serum }}$ of 1.33 (60). Using the average calcium ion concentra- tion in the serum in our series $(1.21 \mathrm{mM}$. per $\mathrm{kgm}$. of water), the calcium concentration of synovial fluid calculated from the above empirical formula is $1.61 \mathrm{mM}$. per $\mathrm{kgm}$. of water in contrast to the observed value of $1.90 \mathrm{mM}$. The difference $(0.29$ $\mathrm{mM}$. per $\mathrm{kgm}$. of water) represents an estimate of the calcium bound by mucin. In terms of millimols of calcium bound per gram of mucin the figure is $0.23 \mathrm{mM}$., a value approximately ten times that obtained for serum proteins (92). This is in agreement with the results of our experiments on pure mucin discussed above, which indicate that the base-combining power of mucin is high.

TABLE V

Concentrations of potassium, magnesium, and sodium in normal cattle serum and synovial fluid

\begin{tabular}{|c|c|c|c|c|c|c|c|c|}
\hline \multirow{2}{*}{$\begin{array}{l}\text { Cow } \\
\text { number }\end{array}$} & \multicolumn{2}{|c|}{ Potassium } & \multirow{2}{*}{$\begin{array}{c}\text { Cow } \\
\text { number }\end{array}$} & \multicolumn{2}{|c|}{ Magnesium } & \multirow{2}{*}{$\begin{array}{c}\text { Cow } \\
\text { number }\end{array}$} & \multicolumn{2}{|c|}{ Sodium } \\
\hline & $\mathrm{Se}$ & $\mathrm{Fl}$ & & $\mathrm{Se}$ & $\mathrm{Fl}$ & & $\mathrm{Se}$ & $\mathrm{Fl}$ \\
\hline & $\begin{array}{c}\text { m.eq. } \\
\text { per } \\
1000 \\
\text { grams } \\
\mathrm{H}_{2} \mathrm{O}^{*}\end{array}$ & $\begin{array}{c}\text { m.eq. } \\
\text { per } \\
1000 \\
\text { grams } \\
\mathrm{H}_{2} \mathrm{O}^{*}\end{array}$ & & $\begin{array}{c}\text { m.eq. } \\
\text { per } \\
1000 \\
\text { grams } \\
\mathrm{H}_{2} \mathrm{O}^{*}\end{array}$ & $\begin{array}{c}\text { m.eq. } \\
\text { per } \\
1000 \\
\text { grams } \\
\mathrm{H}_{2} \mathrm{O}^{*}\end{array}$ & & $\begin{array}{c}\text { m.eq. } \\
\text { per } \\
1000 \\
\text { grams } \\
\mathrm{H}_{2} \mathrm{O}^{*}\end{array}$ & $\begin{array}{c}\text { m.eq. } \\
\text { per } \\
1000 \\
\text { grams } \\
\mathrm{H}_{2} \mathrm{O}^{*}\end{array}$ \\
\hline $\begin{array}{r}\text { XXXV } \\
\text { XXXVII } \\
\text { XXXVIII } \\
\text { XLVII } \\
\text { XLVIII } \\
\text { XLIX }\end{array}$ & $\begin{array}{l}5.46 \\
5.12 \\
5.87 \\
5.87 \\
5.45 \\
4.44\end{array}$ & $\begin{array}{l}4.06 \\
4.10 \\
4.15 \\
4.40 \\
3.60 \\
3.90\end{array}$ & $\begin{array}{r}\text { XXXIX.. } \\
\text { XL.. } \\
\text { XLI.. } \\
\text { XLII.. } \\
\text { XLIII.. } \\
\text { XLIV.. } \\
\text { XLV.. } \\
\text { XLVI.. }\end{array}$ & $\begin{array}{l}1.67 \\
1.71 \\
1.78 \\
2.22 \\
1.54 \\
1.78 \\
1.67 \\
1.61\end{array}$ & $\begin{array}{l}1.37 \\
1.33 \\
1.37 \\
1.54 \\
1.42 \\
1.72 \\
1.45 \\
1.33\end{array}$ & $\begin{array}{r}\text { XVI..... } \\
\text { XVII..... } \\
\text { XVIII..... } \\
\text { XIX..... } \\
\text { XXX..... } \\
\text { XXI.... }\end{array}$ & $\begin{array}{l}148.7 \\
152.9 \\
156.5 \\
155.6 \\
155.1 \\
167.9\end{array}$ & $\begin{array}{l}140.1 \\
147.8 \\
144.2 \\
147.5 \\
143.4 \\
147.1\end{array}$ \\
\hline $\begin{array}{l}\text { Average. ... } \\
\text { Maximal. . } \\
\text { Minimal. . }\end{array}$ & $\begin{array}{l}5.37 \\
5.87 \\
4.44\end{array}$ & $\begin{array}{l}4.04 \\
4.40 \\
3.60\end{array}$ & & $\begin{array}{l}1.75 \\
2.22 \\
1.54\end{array}$ & $\begin{array}{l}1.44 \\
1.72 \\
1.33\end{array}$ & & $\begin{array}{l}156.1 \\
167.9 \\
148.7\end{array}$ & $\begin{array}{l}145.0 \\
147.8 \\
140.1\end{array}$ \\
\hline
\end{tabular}

* Calculated with average figures for water content.

The average ratios $\frac{(\mathrm{K}) f}{(\mathrm{~K}) s}(0.76)$ and $\sqrt{\frac{(\mathrm{Mg}) f}{(\mathrm{Mg}) s}}$ (0.88) were obtained from a smaller number of analyses, the results of which varied considerably. (See Table V.) However, the deviation from the chloride ratio is great and of the same magnitude as that found by other workers, and probably is of significance in spite of the variation in results. One can conclude that part of the potassium (approximately 25 per cent) and part of the magnesium (approximately 30 per cent), as well as part of the calcium, are held in the serum in a non-diffusible state. The variation in results makes it impossible to estimate accurately what proportion is bound in this way.

The average ratio $\frac{\text { (total base) } f}{\text { (total base) } s}(0.98)$ is identical with the chloride ratio. The results of the 
individual determinations of the total base concentration, however, varied markedly. The distribution ratio of total base concentrations obtained by summation of the average concentrations of the individual cations in the fluid and serum is 0.91 . This value may be a more accurate indication of the base held in the serum in a nondiffusible state.

Thus, the distribution of electrolytes agrees, in general, with that expected from the Donnan theory of membrane equilibrium, and with the results obtained by Greene and Power (55) in the study of the in vivo dialysate, and by various workers in the study of other fluids which have been shown to have the composition of dialysates. Therefore, the distribution of electrolytes is in accord with the theory that synovial fluids is a dialysate of blood plasma.

\section{Anatomical considerations}

Having found that the distribution of electrolytes and non-electrolytes is in accord with the concept that synovial fluid is a dialysate, experiments were undertaken to determine whether the vascular supply to the synovial membrane and subsynovial tissues is consistent with this theory.

Employing the same technique previously described (10), the blood vessels of the rear extremities of dogs were perfused with a 6 per cent gum acacia solution. The perfusion was terminated by the injection of a suspension of graphite. This method made possible the filling of the subsynovial blood vessels with a substance that could be easily recognized on macroscopic and microscopic examination.

Gross examination of a knee joint from a leg so perfused (Figure I) demonstrates the existence of a rich subsynovial blood supply. It will be noted that the most vascular areas are the infrapatellar fat pad and the subsynovial tissue immediately adjacent to the patella. On examination of the microscopic sections taken from this same joint (Figure II), one notes that the subsynovial tissues possess a generous blood supply. One further notes that such blood vessels in many instances are separated from the joint cavity by only a few layers of cells. In other sections it was found that 6 to 20 cells intervene between the joint cavity and the blood vessels. Thus, it

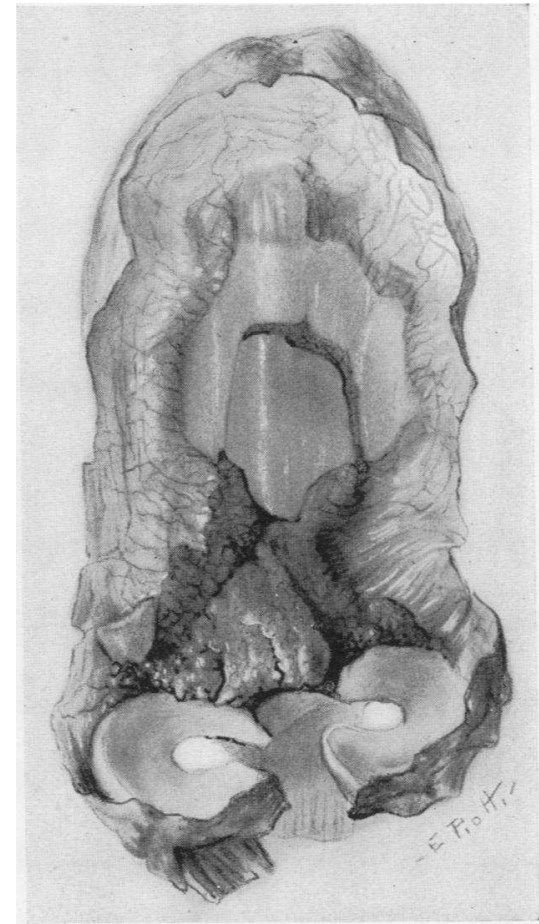

Fig. I. A Natural Sized Drawing of the Interior of the Left Knee Joint of a Normal Dog

The blood vessels of the rear extremities had been perfused with a suspension of graphite. It will be noted that the subsynovial tissues are very vascular, particularly in the region of the infrapatellar fat pad and immediately adjacent to the patella.

would appear that the blood supply to the subsynovial tissues is sufficiently great and so arranged to allow readily for the diffusion of plasma water into the joint cavity. Such anatomical facts lend further support to the interpretation of the chemical findings, namely, that synovial fluid is a dialysate.

\section{COMMENT}

The distribution of electrolytes and non-electrolytes between serum and normal synovial fluid, as well as the nature of the vascular supply of the knee joint, is in accord with the concept that normal synovial fluid is a dialysate in equilibrium with blood plasma. Such a theory explains all known facts of the physical and chemical composition of synovial fluid except the presence of mucin, albumin, and globulin. The presence of mucin, however, in no way invalidates the theory. Whatever the source of the mucin, whether it be the surrounding connective tissue, as seems most 


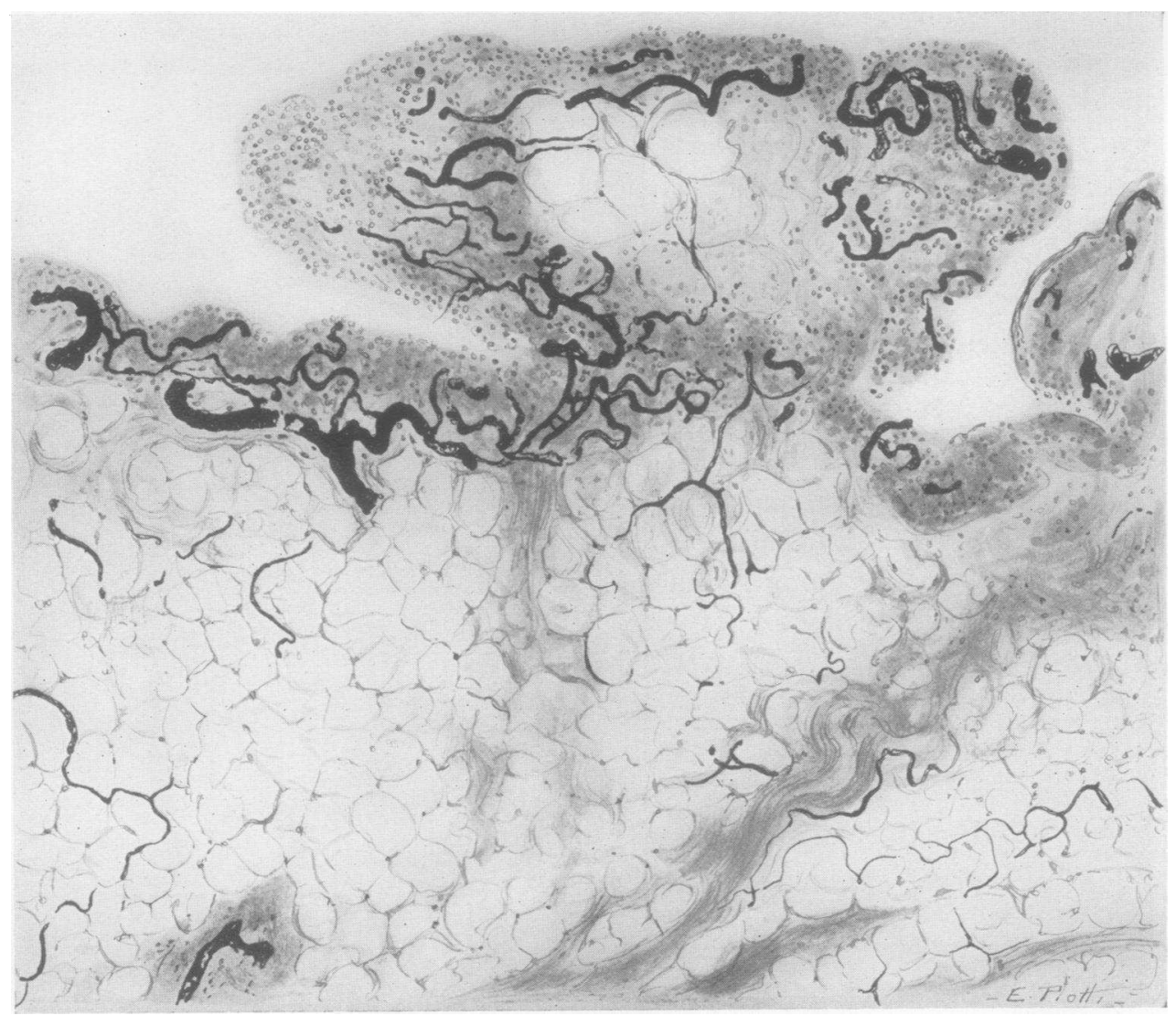

Fig. II. Camera Lucida Drawing of Low Magnification $(\times 100)$ of a Microscopic Section Taken from the Opposite Knee Joint of the One Shown in Figure I

The rich subsynovial vascular system is well illustrated. In some instances the blood capillaries are separated from the interior of the joint by not more than one or two layers of synovial lining cells.

likely, or cartilage, the synovial fluid itself can be formed by dialysis.

Little is known concerning the source of synovial fluid mucin. Kling (77) considers the phenomenon of sac formation in acetic acid as evidence of the secretory nature of synovial fluid. The absence of sac formation in transudates and exudates and its presence in saliva and synovial fluid merely indicate the absence or presence of a sufficient quantity of a mucin to form a sac, and give no evidence as to whether or not the mucin is of secretory origin. Photomicrographic evidence of synovial membrane glands has never been presented, nor have we ever observed such glands in our studies of synovial membrane. In fact, histological studies show that synovial membrane consists of connective tissue varying in type in different portions of the joint and is not a specialized membrane. The only evidence favoring the theory that mucin is formed in cartilage is that of a similarity of staining reactions (5). No chemical identity has been established. Other workers have suggested that mucin is secreted by individual cells of the synovial membrane or that it represents the fluid matrix of the specialized connective tissue lining an enlarged tissue spacethe joint cavity. Whether the process of mucin formation be described as secretion or matrix formation is immaterial because in either instance, connective tissue cell activity is essential. Extraction from the subcutaneous tissue of rabbits and the tissue lining the astragalotibial joints of cattle of a substance similar to synovial fluid mucin as shown by its physical properties and by enzymatic studies (127) suggests that mucin is formed by the connective tissue cells surrounding 
the joint. Its entrance into the joint is made possible by the diffusion of plasma water from the underlying vessels through the subsynovial tissue and membrane.

The presence of albumin and globulin in syno- vial fluid can be explained presumably on the basis of slight capillary permeability to protein as discussed above. Albumin and globulin are found in varying amounts in other body fluids (lymph, edema, pleural, and ascitic fluids) which have been

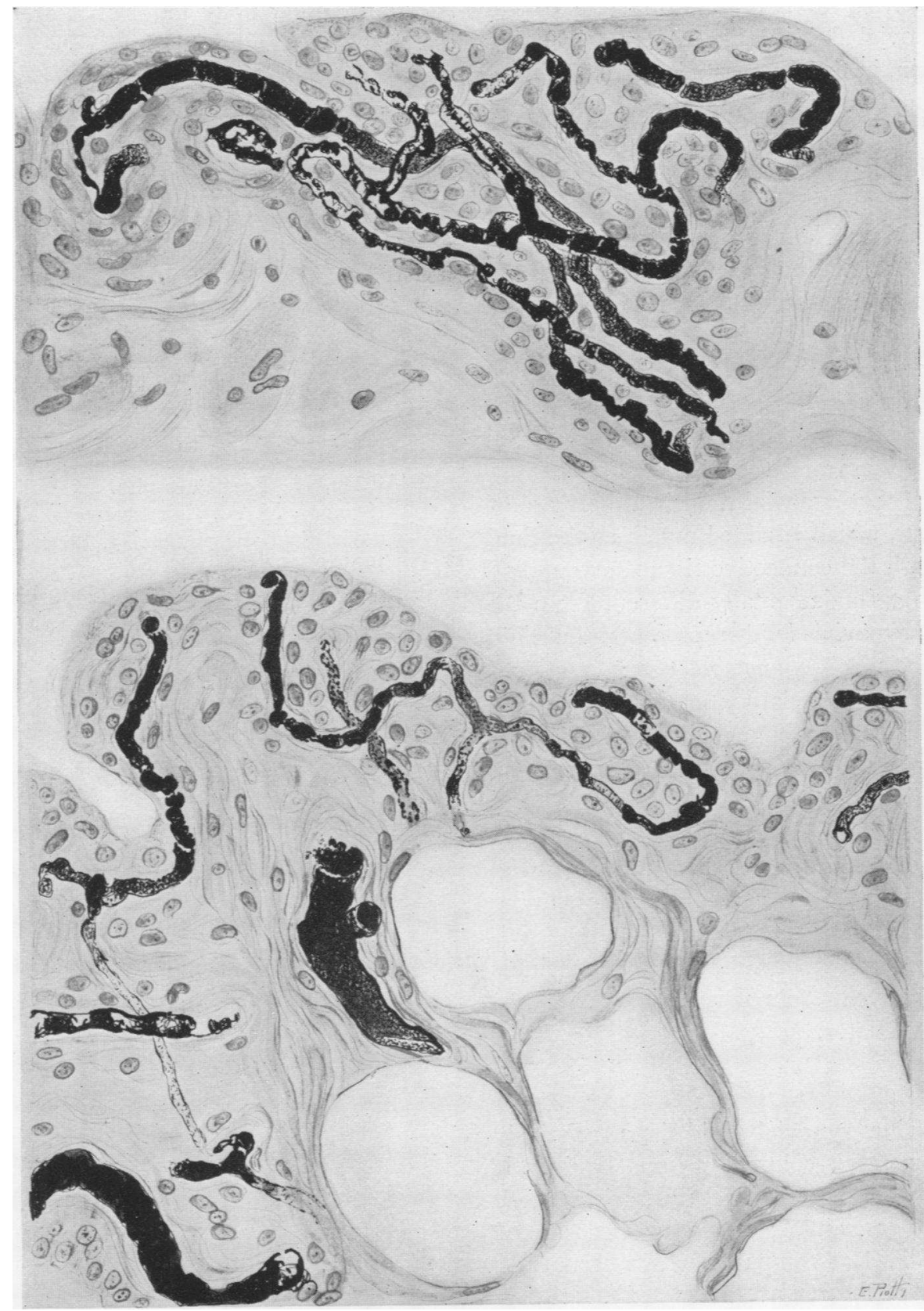

Fig. III. Other Portions of the Synovial Lining Tissues of the Joint Illustrated in Figure II Are Shown in These Camera lucida Drawings of High MagNIFICATION $(\times 420)$.

The close proximity of the blood capillaries to the interior of the joint is evident. 
shown to have the composition of simple dialysates of blood plasma. The high albumin-globulin ratio in the fluid indicates a greater permeability to albumin than to globulin, as suggested also by the observations of other investigators $(33,50,123,124)$.

It is interesting to note that in spite of the fact that synovial fluid, unlike other body fluids, contains mucin, in most respects it resembles these fluids. The only marked differences between the mucin-containing synovial fluid and the other body fluids that have the composition of dialysates of blood plasma are the high colloid osmotic pressure and the high calcium concentration in synovial fluid. The latter finding can be ascribed, presumably, to the high base-combining power of mucin. These effects of mucin in joint fluid are of significance as an indication that mucin, in addition to its action as a lubricant, plays a rôle in the exchange of water and other substances between the vascular system and the joint cavity.

The concept that synovial fluid is a dialysate of blood plasma to which is added mucin as the fluid diffuses through the connective tissue surrounding the joint, is not fundamentally different from the concept that synovial fluid represents the fluid matrix of specialized connective tissue, nor does this theory differ materially from that in which synovial fluid is considered a combination of synovial membrane cell secretion with transudation from the capillaries.

The results of the present investigation give experimental evidence for the theory that synovial fluid is a dialysate of blood plasma containing mucin, albumin, and globulin. Additional evidence is found in the results on human fluids obtained postmortem from normal joints. These will be reported later.

\section{SUMMARY}

Normal bovine synovial fluid is a relatively acellular, clear, straw-colored, viscous liquid. It has the following characteristics: a nucleated cell count of 131 per cu.mm.; a relative viscosity of 3.72 ; a $\mathrm{pH}$ of 7.31 as compared with a serum $\mathrm{pH}$ of 7.42 (average figures are presented).

The total protein concentration is 1.02 grams per 100 grams of water, of which 0.71 gram per cent is albumin, 0.17 globulin and 0.14 mucin. Fibrinogen is absent.
The distribution of electrolytes and non-electrolytes between serum and fluid is in accord with the concept that synovial fluid is a dialysate of blood plasma.

The nature of the subsynovial vascular supply to the knee joint is in accord with this concept.

Unlike other body fluids that are dialysates of blood plasma, synovial fluid contains mucin, the origin of which is unknown. The effect of mucin on the colloid osmotic pressure and calcium concentration of synovial fluid indicates that mucin, in addition to its action as a lubricant, also plays a rôle in the exchange of water and other substances between the vascular system and the joint cavity.

\section{BIBLIOGRAPHY}

1. Aeby, C., Ein Lehrbuch der Anatomie. Der Bau des menschlichen Körpers mit besonderer Rücksicht auf seine morphologische und physiologische Bedeutung. Leipzig, 1868-1871. Cited by Mayeda.

2. Allison, N., Fremont-Smith, F., Dailey, M. E., and Kennard, M. A., Comparative studies between synovial fluid and plasma. J. Bone and Joint Surg., 1926, 8, 758.

3. Arnold, R. M., and Mendel, L. B., Interrelationships between the chemical composition of the blood and the lymph of the dog. J. Biol. Chem., 1927, 72, 189.

4. Aschoff, L., Pathologische Anatomie. II. G. Fischer, Jena. 1911, p. 233.

5. Banchi, A., Ricerche intorno alla struttura della sinoviale, ed alla presunta origine della sinovia. Atti d. Accad. med. fis. Fiorent, Firenze, 1902, 190, 25.

6. Bauer, W., Bennett, G. A., Marble, A., and Claflin, D., Observations on the normal synovial fluid of cattle. I. The cellular constituents and nitrogen content. J. Exper. Med., 1930, 52, 835.

7. Bauer, W., Short, C. L., and Bennett, G. A., The manner of removal of proteins from normal joints. J. Exper. Med., 1933, 57, 419.

8. Béclard, P. A., Eléments d'anatomie générale. Paris, 1865, 4th ed. Cited by Hammar and Mayeda.

9. Benedict, S. R., and Behre, J. A., The analysis of whole blood. III. Determination and distribution of uric acid. J. Biol. Chem., 1931, 92, 161.

10. Bennett, G. A., Bauer, W., and Maddock, S. J., A study of the repair of articular cartilage and the reaction of normal joints of adult dogs to surgically created defects of articular cartilage, "joint mice" and patellar displacement. Am. J. Path., 1932, 8, 499.

11. Bernstein, J., Lehrbuch der Physiologie des thierischen Organismus, im Speciellen des Menschen. Stuttgart, 1894. Cited by Mayeda.

12. Bichat, X., Anatomie Générale, Appliquée à La 
Physiologie et à La Médecine. Paris, 1812, 4, part 2, p. 538.

13. Bick, E. M., Surgical pathology of synovial tissue. J. Bone and Joint Surg., 1930, 12, 33.

14. Bloor, W. R., The determination of cholesterol in blood. J. Biol. Chem., 1916, 24, 227.

15. Boots, R. H., and Cullen, G. E., The hydrogen ion concentration of joint exudates in rheumatic fever and other forms of arthritis. J. Exper. Med., 1922, 36, 405.

16. Brinton, W. in Todd, R. B., Cyclopaedia of Anatomy and Physiology. London, 1847-49, 4, part 1, p. 511. Cited by Hammar.

17. Brull, L., Contribution à L'Etude de L'État Physicochimique des Constituants Minéraux et du Glucose Plasmatiques. Arch. internat. de physiol., 1930, 32, 138.

18. Butler, A. M., and Montgomery, H., The solubility of the plasma proteins. I. Dependence on salt and plasma concentrations in concentrated solutions of potassium phosphate. J. Biol. Chem., 1932, 99, 173.

19. Cajori, F. A., Crouter, C. Y., and Pemberton, R., The physiology of synovial fluid. Arch. Int. Med., 1926, 37, 92.

20. Cajori, F. A., and Pemberton, R., The chemical composition of synovial fluid in cases of joint effusion. J. Biol. Chem., 1928, 76, 471.

21. Cherry, J. H., and Ghormley, R. K., A histopathological study of the synovial membrane with mucicarmine staining. J. Bone and Joint Surg., 1938, $20,48$.

22. Churchill, E. D., Nakazawa, F., and Drinker, C. K., The circulation of body fluids in the frog. Am. J. Physiol., 1927, 63, 304.

23. Collins, D. H., The pathology of synovial effusions. J. Path. and Bact., 1936, 42, 113.

24. Conklin, R., The formation and circulation of lymph in the frog. III. The permeability of the capillaries to protein. Am. J. Physiol., 1930, 95, 98.

25. Cornil, A. V., and Ranvier, L., Manuel d'histologie pathologique. Paris, 1901, 3d ed., p. 38.

26. Darrow, D. C., Hopper, E. B., and Cary, M. K, Plasmapheresis edema. II. The effect of reduction of serum protein on the electrolyte pattern and calcium concentration. J. Clin. Invest., 1932, 11, 701.

27. Drechsel, E., Chemi der Absonderung und der Gewebe. Herrmann-Handbuch der Physiologie, 1883, 5, Abt. 1, p. 617.

28. Drinker, C. K., and Field, M. E., The protein content of mammalian lymph and the relation of lymph to tissue fluid. Am. J. Physiol., 1931, 97, 32.

29. Drinker, C. K., Field, M. E., Heim, J. W., and Leigh, O. C., Jr., The composition of edema fluid and lymph in edema and elephantiasis resulting from lymphatic obstruction. Am. J. Physiol., 1934, 109, 572.

30. Eisenman, A. J., A note on the Van Slyke method for the determination of chlorides in blood and tissue. J. Biol. Chem., 1929, 82, 411.

31. Fick, R. A., Handbuch der Anatomie und Mechanik der Gelenke unter Berücksichtigung der bewegenden Muskeln. Jena, 1904-11, 3 volumes. Cited by Mayeda.

32. Field, M. E., and Drinker, C. K., The permeability of the capillaries of the dog to protein. Am. J. Physiol., 1931, 97, 40.

33. Field, M. E., Leigh, O. C., Jr., Heim, J. W., and Drinker, C. K., The protein content and osmotic pressure of blood serum and lymph from various sources in the dog. Am. J. Physiol., 1934-35, 110, 174.

34. In Findlay, A., Practical Physical Chemistry. Longmans, Green, \& Company, New York, 1929.

35. Fisher, A. G. T., Chronic (Non-Tuberculous) Arthritis. Macmillan Company, New York, 1929.

36. Fiske, C. H., A method for the estimation of total base in urine. J. Biol. Chem., 1922, 51, 55.

37. Fiske, C. H., and Litarczek, G. Unpublished data.

38. Fiske, C. H., and Logan M. A., In Folin's Laboratory Manual of Biological Chemistry. Determination of Calcium. Appleton-Century Co., New York, 1934, 5th ed., p. 349.

39. Fiske, C. H., and Logan, M. A., In Folin's Laboratory Manual of Biological Chemistry. Determination of Magnesium in Urine. Appleton-Century Co., New York, 1934, 5th ed., p. 237.

40. Fiske, C. H., and Subbarow, Y., The colorimetric determination of phosphorus. J. Biol. Chem., 1925, 66, 375.

41. Folin, O., Two revised copper methods for blood sugar determination. J. Biol. Chem., 1929, 82, 83.

42. Folin, O., and Wu, H., A system of blood analysis. J. Biol. Chem., 1919, 38, 81.

43. Forkner, C. E., The synovial fluid in health and disease with special reference to arthritis. J. Lab. and Clin. Med. 1930, 15, 1187.

44. Fremont-Smith, F., Thomas, G. W., Dailey, M. E., and Carroll, M. P., The equilibrium between cerebrospinal fluid and blood-plasma. V. The osmotic pressure (freezing-point depression) of human cerebrospinal fluid and blood-serum. Brain, 1931, 54, 303.

45. Frerichs, F. T., in Wagner, R., Handwörterbuch der Physiologie, mit Rücksicht auf physiologische Pathologie. 1846, III, Abt. 1, Synovia, p. 463.

46. Frey, H., Compendium of Histology. Putnam, New York, 1876. (Translated by George R. Cutter.)

47. Friedemann, T. E., Cotonio, M., and Shaffer, P. A., The determination of lactic acid. J. Biol. Chem., 1927, 73, 335.

48. Gilligan, D. R., Volk, M. C., and Blumgart, H. L., Observations on the chemical and physical relation between blood serum and body fluids. II. The chemical relation between serum and edema fluids as compared with that between serum and cerebrospinal fluid. New England J. Med., 1934, 210, 896. 
49. Gilligan, D. R., Volk, M. C., and Blumgart, H. L., Observations on the chemical and physical relation between blood serum and body fluids. I. The nature of edema fluids and evidence regarding the mechanism of edema formation. J. Clin. Invest., 1934, 13, 365.

50. Goettsch, E., and Kendall, F. E., Analysis of albumin and globulin in biological fluids by the quantitative precipitin method. J. Biol. Chem., 1935, 109, 221.

51. Gollwitzer-Meier, K., Zur Odempathogenese. Ztschr. f. d. ges. exper. Med., 1925, 46, 15.

52. Gosselin, L. A., Recherches sur les Kystes synoviaux de la main et du poignet. Mém. acad. de méd., 1852, 16, 367. Cited by Mayeda.

53. Govaerts, $P$., Influence de la Teneur du Sérum en Albumines et en Globulines sur la Pression Osmotique des Protéines et sur la Formation des Oedèmes. Bull. Acad. roy. de méd. de Belgique, 1927, 7, 356.

54. Greene, C. H., Bollman, J. L., Keith, N. M., and Wakefield, E. G., The distribution of electrolytes between serum and transudates. J. Biol. Chem., 1931, 91, 203.

55. Greene, C. H., and Power, M. H., The distribution of electrolytes between serum and the in vivo dialysate. J. Biol. Chem., 1931, 91, 183.

56. Hagen-Torn, O., Entwickelung und Bau der Synovialmembranen. Arch. f. mikr. Anat., 1882, 21, 591.

57. Hammar, J. A., Ueber den feineren Bau der Gelenke. Arch. f. mikr. Anat. 1894, 43, 266.

58. Hare, T., and Cohen, H., The chemical estimation of the synovial fluid and blood-serum of horses affected with chronic arthritis. Proc. Roy. Soc. Med., 1929, 22, 1121.

59. Hartmann, R., Lehrbuch der Anatomie des Menschen für Studirende und Aerzte. Strasburg, 1881. Cited by Mayeda.

60. Hastings, A. B. Unpublished data.

61. Hastings, A. B., Salvesen, H. A., Sendroy, J., Jr., and Van Slyke, D. D., Studies of gas and electrolyte equilibria in the blood. IX. The distribution of electrolytes between transudates and serum. J. Gen. Physiol., 1927, 8, 701.

62. Havers, C., Osteologia nova, or Some New Observations on the Bones and the Parts Belonging to Them, with the Manner of Their Accretion and Nutrition-in Several Discourses. London, 1691. Cited by Hammar.

63. Heim, J. W., On the chemical composition of lymph from subcutaneous vessels. Am. J. Physiol., 1933, 103, 553.

64. Henle, J., Allgemeine Anatomie, Lehre von den Mischungs- und Formbestandtheilen des menschlichen Körpers. Leopold Voss, Leipzig, 1841, p. 385.

65. Hildebrand, O., Die Entstehung des Gelenkhydrops und seine Behandlung. Arch. f. klin. Chir., 1906, 81, 412. Cited by Mayeda.
66. Horiye, $K$, Uber die menschliche Synovia. Virch. Arch. f. path. Anat., 1924, 251, 649.

67. Howe, P. E., The determination of proteins in blood-A micro method. J. Biol. Chem., 1921, 49, 109.

68. Hueck, W., Uber das Mesenchym. Beitr. z. path. Anat. u. z. allg. Path., 1920, 66, 330.

69. Hueter, C., Zur Histologie der Gelenkflächen und Gelenkkapseln, mit einem kritischen Vorwort über die Versilberungsmethode. Virch. Arch. f. path. Anat., 1866, 36, 25.

70. Hyrtl, J., Lehrbuch der Anatomie des Menschen, mit Rücksicht auf physiologische Begründung und praktische Anwendung. Braumüller, Wien, 1878, p. 134.

71. Jones, H. T., Cystic bursal hygromas. J. Bone and Joint Surg., 1930, 12, 45.

72. Keefer, C. S., Myers, W. K., and Holmes, W. F., Jr., Characteristics of the synovial fluid in various types of arthritis. Arch. Int. Med., 1934, 54, 872.

73. Key, J. A., Cytology of the synovial fluid of normal joints. Anat. Rec., 1928, 40, 193.

74. Key, J. A., In Special Cytology, II. The Synovial Membrane of Joints and Bursae. Paul B. Hoeber, Inc., New York, 1928, p. 735.

75. King, E. S. J., The golgi apparatus of synovial cells under normal and pathological conditions and with reference to the formation of synovial fluid. $J$. Path. and Bact., 1935, 41, 117.

76. Kling, D. H., Synovial cells in joint effusions. J. Bone and Joint Surg., 1930, 12, 867.

77. Kling, D. H., The nature and origin of synovial fluid. Arch. Surg., 1931, 23, 543.

78. von Kölliker, A., Mikroskopische Anatomie, oder Gewebelehre des Menschen. II. Leipzig, 1850. Cited by Hammar.

79. Krogh, A., The Anatomy and Physiology of Capillaries. Yale University Press, New Haven, 1929.

80. Krogh, A., Landis, E. M., and Turner, A. H., The movement of fluid through the human capillary wall in relation to venous pressure and to the colloid osmotic pressure of the blood. J. Clin. Invest., 1932, 11, 63.

81. Krogh, A., and Nakazawa, F., Beiträge zur Messung des Kolloid-osmotischen Druckes in Biologischen Flüssigkeiten. Biochem. Ztschr., 1927, 188, 241.

82. Labor, M., and Balogh, E. v., Zytologische und Serologische Untersuchungen der Synovia im Besondern bei Akuten Gelenksentzündungen. Wien. klin. Wchnschr., 1919, 32, 535.

83. Landis, E. M., Capillary pressure and capillary permeability. Physiol. Rev., 1934, 14, 404.

84. Landis, E. M., Jonas, L., Angevine, M., and Erb, W., The passage of fluid and protein through the human capillary wall during venous congestion. $\mathrm{J}$. Clin. Invest., 1932, 11, 717.

85. von Langer, C., Lehrbuch der systematischen und topographischen Anatomie. Wien, 1885. Cited by Mayeda. 
86. Lieboff, S. L., and Kahn, B. S., A rapid and accurate method for the determination of urea in the blood. J. Biol. Chem., 1929, 83, 347.

87. Loeb, R. F., Atchley, D. W., and Palmer, W. W., On the equilibrium condition between blood serum and serous cavity fluids. J. Gen. Physiol., 1922, 4, 591.

88. Maly, R., Ueber die Aenderung der Reaction (in der Lösung eines Salzgemisches) durch Diffusion und die dadurch mögliche Erklärung beim Vorgange der Secretion von sauren Harn aus alkalischem Blute. Berichte der Chem. Gesellschaft zu Berlin, 1876, 9, 164.

89. Man, E. B., and Peters, J. P., Permeability of capillaries to plasma lipoids. J. Clin. Invest., 1933, $12,1031$.

90. Mayeda, T., Experimentelle histologische Studie über die Synovialmembran. Mitt. a. d. Med. Fakult. d. k. Univ. zu Tokyo, 1919-20, 23, 393.

91. McEwen, C., Cytologic studies on rheumatic fever. II. Cells of rheumatic exudates. J. Clin. Invest., $1935,14,190$.

92. McLean, F. C., and Hastings, A. B., The state of calcium in the fluids of the body. I. The conditions affecting the ionization of calcium. J. Biol. Chem., 1935, 108, 285.

93. Meyer, A. W., Lehrbuch der Anatomie. 1861. Cited by Mayeda.

94. Moore, N. S., and Van Slyke, D. D., The relationships between plasma specific gravity, plasma protein content and edema in nephritis. J. Clin. Invest., 1929-30, 8, 337.

95. Muntwyler, E., Way, C. T., and Pomerene, E., A comparison of the chloride and bicarbonate concentrations between plasma and spinal fluid and plasma and ascitic fluid in reference to the Donnan equilibrium. J. Biol. Chem., 1931, 92, 733.

96. Myers, W. K., Keefer, C. S., and Holmes, W. F., Jr., The characteristics of synovial fluid in gonococcal arthritis. J. Clin. Invest., 1934, 13, 767.

97. Ogston, A., On articular cartilage. J. Anat. and Physiol., 1875, 10, 49.

98. Peters, J. P., Body Water. Thomas, Springfield, 1935.

99. Rainey, G. London, Edinburgh and Dublin Philosoph. Magazine. On the Anatomy and Physiology of the Vascular Fringes in Joints and Tendons. 1846, Volume 29. Cited by Hammar.

100. Rauber, A. A., Lehrbuch der Anatomie des Menschen. Leipzig, 1908. Cited by Mayeda.

101. Rourke, M. D., On the determination of the sodium content of small amounts of serum or heparinized plasma by the iodometric method. J. Biol. Chem., 1928, 78, 337.

102. Schmidt, C. L. A., and Greenberg, D. M., Occurrence, transport and regulation of calcium, magnesium and phosphorus in the animal organism. Physiol. Rev., 1935, 15, 297.

103. Schneidermühl, G., Beitrag zum feineren Bau der
Gelenke bei den grösseren Hausthieren, speciell des Kniegelenks beim Pferde. Arch. f. wissensch. u. prakt. Thierh., 1884, 10, 40.

104. Schneider, J., Untersuchungen über die Viskosität menschlicher Synovia. Biochem. Ztschr., 1925, 160, 325.

105. Schrant, J. M., Der Ursprung des Colloids: nach dem Holländischen von C. E. Weber, Separatabdruck s. e. Cited by Hammar.

106. Seeliger, P., Ein Beitrag zur pathologischen Physiologie der Gelenke unter Berücksichtigung der Gelenkmausbildung. Arch. f. klin. Chir., 1926, 142, 606.

107. Soubbotine, M., Recherches histologiques sur la structure des membranes synoviales. Arch. de Physiol. norm. et path., s. 2, 1880, 7, 532.

108. Stoddard, J. L., and Drury, P. E., A titration method for blood fat. J. Biol. Chem., 1929, 84, 741.

109. Talbott, J. H., and Michelsen, J., Heat cramps. A clinical and chemical study. J. Clin. Invest., 1933, 12, 533.

110. Tillmanns, H., Beiträge zur Histologie der Gelenke. Arch. f. mikr. Anat., 1874, 10, 401.

111. Thompson, W. O., Thompson, P. K., and Dailey, M. E., The effect of posture upon the composition and volume of the blood in man. J. Clin. Invest., 1927-28, 5, 573.

112. Todd, R. B., and Bowman, W., Physiological Anatomy and Physiology of Man. Longmans, London, 1856, I, p. 126.

113. Van Slyke, D. D., Hastings, A. B., Hiller, A., and Sendroy, J., Jr., Studies of gas and electrolyte equilibria in blood. XIV. The amounts of alkali bound by serum albumin and globulin. J. Biol. Chem., 1928, 79, 769.

114. Van Slyke, D. D., and Neill, J. M., The determination of gases in blood and other solutions by vacuum extraction and manometric measurement. J. Biol. Chem., 1924, 61, 523.

115. Van Slyke, D. D., Wu, H., and McLean, F. C., Studies of gas and electrolyte equilibria in the blood. V. Factors controlling the electrolyte and water distribution in the blood. J. Biol. Chem., $1923,16,765$.

116. Vaubel, E., The form and function of synovial cells in tissue cultures. II. The production of mucin. J. Exper. Med., 1933, 58, 85.

117. von Holst, G., Serosamucin, eine Mucinsubstanz in Ascitesflüssigkeit und Synovia. Ztschr. f. physiol. Chem., 1904, 43, 145.

118. Walker, A. M., Quantitative studies of the composition of glomerular urine. $X$. The concentration of inorganic phosphate in glomerular urine from frogs and necturi determined by an ultramicromodification of the Bell-Doisy method. J. Biol. Chem., 1933, 101, 239.

119. Walker, A. M., Comparison of the chemical composition of aqueous humor, cerebrospinal fluid, lymph and blood from frogs, higher animals, and 
man. Reducing substances, inorganic phosphate, uric acid, urea. J. Biol. Chem., 1933, 101, 269.

120. Walker, A. M., and Reisinger, J. A., Quantitative studies of the composition of glomerular urine. IX. The concentration of reducing substances in glomerular urine from frogs and necturi determined by an ultramicro-adaptation of the method of Sumner. Observations on the action of phlorhizin. J. Biol. Chem., 1933, 101, 223.

121. Waterfield, R. L., The effects of posture on the circulating blood volume. J. Physiol., 1931, 72, 110.

122. Warren, C. F., Bennett, G. A., and Bauer, W., The significance of the cellular variations occurring in normal synovial fluid. Am. J. Path., 1935, 11, 953.

123. Weech, A. A., Goettsch, E., and Reeves, E. B., The proteins of blood and subcutaneous lymph in dogs. J. Clin. Invest., 1931, 12, 1021.

124. Wells, H. S., The concentration and osmotic pressure of the proteins in blood serum and in lymph from the lacteals of dogs. Am. J. Physiol., 1932, $101,421$.

125. Youmans, J. B., Wells, H. S., Donley, D., Miller, D. G., and Frank, H., The effect of posture (standing) on the serum protein concentration and colloid osmotic pressure of blood from the foot in relation to the formation of edema. $J$. Clin. Invest., 1934, 13, 447.

126. Zsigmondy, R., and Bachmann, W., Uber neue Filter. Ztschr. f. anorg. u. allgem. Chemie, 1918, 103, 119. 119.

127. Unpublished data. 